\title{
Formation of Hydrogen Bonds; Hydroxyl and Methyl Groups Dynamics in 2,2-dimethylbutan-1-ol and 2,3-dimethylbutan-2-ol: DFT, IINS and IR Investigations
}

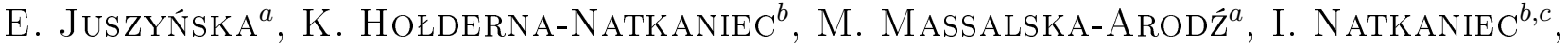 \\ E. ŚCIESIŃSKA ${ }^{a}$ AND J. ŚCIESIŃSKI ${ }^{a}$ \\ ${ }^{a}$ The H. Niewodniczański Institute of Nuclear Physics, PAS, E. Radzikowskiego 152, 31-342 Kraków, Poland \\ ${ }^{b}$ Faculty of Physics, A. Mickiewicz University, Umultowska 85, 61-614 Poznań, Poland \\ ${ }^{c}$ Frank Laboratory of Neutron Physics, JINR, 141980 Dubna, Russia
}

(Received February 29, 2012; in final form July 21, 2012)

\begin{abstract}
Dynamics of 2,2-dimethylbutan-1-ol and 2,3-dimethylbutan-2-ol have been studied by experimental spectroscopy methods, i.e., inelastic incoherent neutron scattering and infrared absorption. Experimental results were discussed and compared with the results of the quantum chemical calculations performed by semi-empirical PM3 and the density functional theory methods assuming the isolated molecule and dimer, trimer and tetramer clusters. The density functional theory modelling of vibrational spectra of monomers and $\mathrm{OH}$ bonded molecular clusters allows to assign the inter- and intermolecular vibrational modes observed in density of states and absorption spectra.
\end{abstract}

PACS: 82.30.Rs, 82.80.Gk, 78.70.Nx, 31.15.A-

\section{Introduction}

The 2,2-dimethylbutan-1-ol, i.e., neohexanol (2,2-DM-1-B) - $\mathrm{CH}_{3} \mathrm{CH}_{2} \mathrm{C}\left(\mathrm{CH}_{3}\right)_{2} \mathrm{CH}_{2} \mathrm{OH}$ and 2,3-dimethylbutan-2-ol (2,3-DM-2-B) - $\left(\mathrm{CH}_{3}\right)_{2} \mathrm{CHC}\left(\mathrm{CH}_{3}\right)_{2} \mathrm{OH}$ are the isomers of the $\mathrm{C}_{6} \mathrm{H}_{13} \mathrm{OH}$ summary chemical formula [1-11]. Various molecular structures affect the polymorphism of these alcohols and dynamics as well. The symmetry group for molecules is $C 1$. They have nearly globular shapes thanks to branched structures. This has impact on the formation of the orientationally disordered plastic crystal (ODIC) phases [10, 12-14]. Recently polymorphism and dynamics of both substances were studied by differential thermal analysis (DTA) [4-6], differential scanning calorimetry (DSC) [7-10], adiabatic calorimetry [8-11] and dielectric relaxation $[2-6,8,10,11]$ methods. In adiabatic calorimetry measurements of 2,2-DM-1-B [8-10] four solid phases have been found, i.e., the ordered crystal $\mathrm{C} 3$, two ODIC phases $\mathrm{C} 2$ and $\mathrm{C} 1$ and glass of C2 rotatory phase [12-14]. Glass of phase C2 was obtained in cooling run performed with $5 \mathrm{~K} / \mathrm{min}$ rate. The softening of glass was determined at $123 \mathrm{~K}$.

On further heating the metastable phase $\mathrm{C} 2$ transformed through several metastable crystalline phases to the stable crystal $\mathrm{C} 3$ at $180 \mathrm{~K}$. Then, the following phase sequence was detected: C3 (194.9 K) $\rightarrow$ C2 $(209 \mathrm{~K}) \rightarrow$ $\mathrm{C} 1(233 \mathrm{~K}) \rightarrow$ Is.

For 2,3-DM-2-B two crystalline phases $\mathrm{C} 2$ and $\mathrm{C} 1$ were found using adiabatic calorimetry method [9-11]. The phase sequence observed is the following: $\mathrm{C} 2(249.8 \mathrm{~K}) \rightarrow$ C1 $(262 \mathrm{~K}) \rightarrow$ Is. No glass phase was found there. For both dipolar substances in the rotatory phases complex molecular dynamics were found by dielectric relaxation method giving very small dielectric increments. The fast $\mathrm{MHz}$ relaxation was related to $\mathrm{OH}$ group motions.
Moreover, reorientations of whole molecules ( $\alpha$-process) were detected: for 2,2-DM-1-B a single relaxation process while for 2,3-DM-2-B two processes associated with different conformers $[2-6,8,10,11,15]$.

In the inelastic incoherent neutron scattering (IINS) experiment identification of polymorphism and vibrational dynamics have been performed in wide temperature range from $20 \mathrm{~K}$ to $300 \mathrm{~K}$ [10, 16-23]. For 2,2-DM-1$\mathrm{B}$ the IINS spectra of glass of plastic crystalline phase $\mathrm{C} 2$ obtained in fast cooling and of the ordered crystal phase C3 obtained in slow cooling have been observed at $20 \mathrm{~K}$ $[10,17,24-26]$. In the IINS studies of 2,3-DM-2-B at low temperature vibrational spectra of crystalline phase $\mathrm{C} 2$ have been obtained after slow and rapid cooling of the sample $[10,16,17]$.

This work presents the results of the observations of the vibrational modes in 2,2-DM-1-B and 2,3-DM-2-B with help of the IINS method and the middle infrared (MIR) absorption spectroscopy. In addition, for 2,2-DM-1-B the far infrared (FIR) spectroscopy results were carried out. For interpretation of the bands observed in the density of states (at $20 \mathrm{~K}$ ) and absorption spectra (at $290 \mathrm{~K}$ ) frequencies and intensities of the normal modes were calculated for the isolated molecules and simple molecular clusters, using $a b$ initio density functional theory (DFT) method. Vibration bands of the hydroxyl group forming the hydrogen bonds are indicated [27, 28].

\section{Methods}

The neohexanol isomer 2,3-DM-2-B was purchased from Aldrich Chemical Company and the 2,2-D-1-B sample was synthesised in the Jerzy Haber Institute of Catalysis and Surface Chemistry, Polish Academy of Sciences, Kraków. 
The IINS spectra for both DMB substances have been measured in the energy range up to $1600 \mathrm{~cm}^{-1}$ at temperatures from 20 to $290 \mathrm{~K}$. The NERA-PR inverted geometry time-of-flight spectrometer installed at the IBR-2 high-flux pulsed reactor in the JINR, Dubna, Russia, was used. The experimental techniques have been described previously in numerous literature positions [10, 16-23]. The middle-infrared Fourier transform absorption measurements (MIR) were performed using the EXCALIBUR FTS 3000 spectrometer in the wave number range from $400 \mathrm{~cm}^{-1}$ to $4000 \mathrm{~cm}^{-1}$. The MIR absorption spectra of both DMB substances have been obtained at room temperature $(\approx 290 \mathrm{~K})$ in the liquid phase $[7,10]$. In the MIR spectra the stretching modes are observed preferably. The far-infrared Fourier transform absorption measurements (FIR) have been carried out only for 2,2-DM-1-B with the DIGILAB FTS14 spectrometer in the frequency range of $40-500 \mathrm{~cm}^{-1}$, with the resolution $2 \mathrm{~cm}^{-1}$. The temperature dependence of the FIR absorption spectra has been measured in the 25-290 $\mathrm{K}$ temperature range.

The IINS method in contrast to the IR absorption spectroscopy is excellent to "see" the rotational dynamics of the molecular groups containing hydrogen. However, detection of the vibrations of $\mathrm{OH}$ groups in isomers of dimethylbutanol is not so evident because neutron scattering cross-section is dominated by protons of methyl groups.

For the investigation of formation of hydrogen bonds [27-32] and for interpretation of vibrational spectrum from IINS and IR experiments performed for 2,2-DM-1$\mathrm{B}$ and 2,3-DM-2-B computational methods of quantum chemistry have been used for modelling structure and dynamics of the monomer and then of dimer, trimer and cyclic tetramer clusters, created through hydrogen bonding (HB) interactions. In first step the geometry of isolated molecule has been optimized by the semi-empirical PM3 method [32] because its conformational structure is unknown. In the second step, the structure has been optimized using the DFT method [34]. The Gaussian 03 program [35] was used to calculate the frequencies and intensities of the normal vibrations bands of the spectra of density of states $G_{\text {cal }}(\nu)$ and IR absorption for isolated molecules and dimer clusters (base 6-311G(d, p)) [36]. Calculation for trimer and tetramer clusters were performed on different level (base 6-31G) [36]. The calculations of the geometrical structure of molecules and the frequency and intensity of harmonic vibrations were performed using approximate nonlocal functionals: B3LYP (including various exchange energies proposed by Becke and correlation energy functional of Lee, Young and Parr) [37-39] and Gausche base-type [36] wave functions $6-311 \mathrm{G}(\mathrm{d}, \mathrm{p})$. Molecular geometry optimization for the lowest energy conformation of isolated molecules and clusters was performed. Then, for the optimized structure, frequencies of harmonic vibrations and intensities of IR bands were calculated. Classification was carried out taking into account the distribution of vibrations result- ing from the nature of the internal coordinate's changes (stretching, deformation and torsion vibrations). The DFT calculations allow to establish the frequencies $\nu_{j}$ of the normal modes and displacements $A_{n}\left(\nu_{j}\right)$ in corresponding normal mode $j$ of a molecule of $n$ atoms. Amplitude weighted density of states $G_{\text {cal }}(\nu)$ is described as

$$
G(\nu) \sim \sum_{j} \sum_{n}\left[A_{j}^{n}\left(\nu_{j}\right)\right]^{2} \delta\left(\nu-\nu_{j}\right)
$$

The incoherent inelastic neutron scattering cross-section, which is determined by $G_{\text {cal }}(\nu)$, has been obtained by the $\alpha$-Climax program [40] using the results of atomic displacements and normal modes frequencies obtained from Gaussian program. Next, the program Resol [20] was used to perform convolution of the Dirac delta functions with resolution function of the NERA-PR spectrometer and to calculate the IINS time of flight (TOF) spectra. The experimental and calculated IINS-TOF spectra have been compared after transformation to the weighted amplitude of the density of vibrational states in approximation of one-phonon incoherent scattering process [19-23].

\section{Results}

\subsection{Isolated molecules}

The structures of the lowest energy of trans and gauche conformers of 2,2-DM-1-B and 2,3-DM-2-B calculated on the B3LYP/6-311G** level are displayed in Fig. 1a-d. The parameters of geometry for both isomers studied are shown in details in Table I. The optimized molecular structure of isolated molecule obtained by the PM3 method is close to that determined by DFT method.

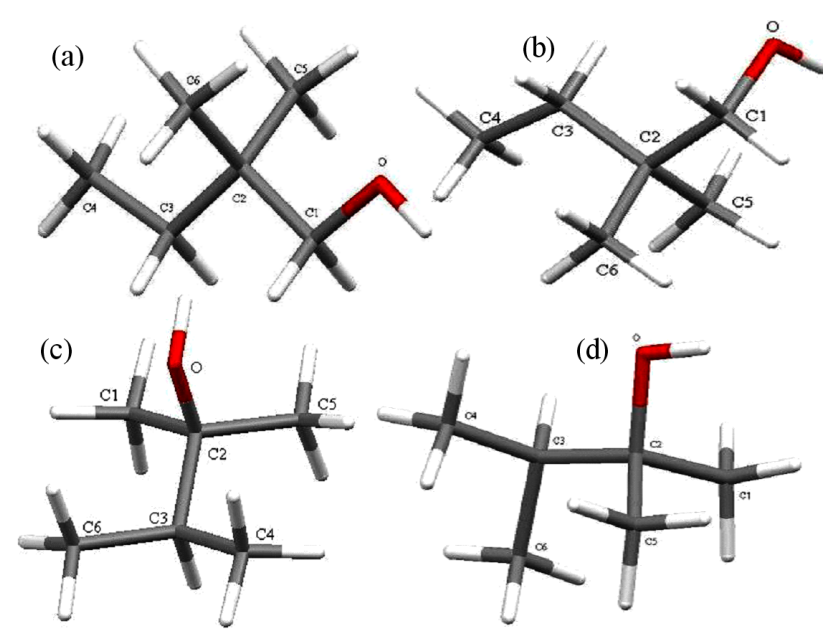

Fig. 1. Geometry of trans (a, c) and gauche (b, d) conformers of 2,2-dimethylbutan-1-ol (a, b) and 2,3-dimethylbutan-2-ol (c, d).

The structure of the 2,2-DM-1-B and 2,3-DM-2-B molecules calculated by DFT method have the electronic energy $\left(E_{\mathrm{e}}\right)$ of $-312.38 \mathrm{Ha}$ and $-312.39 \mathrm{Ha}$, respectively. The energy of studied isomers (2,2-DM-1-B and 


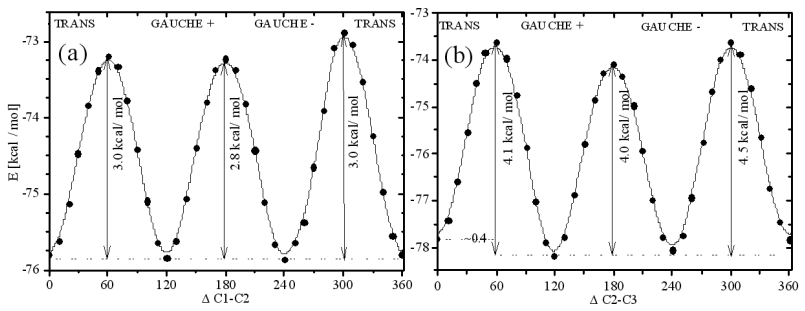

Fig. 2. Energy of molecule as a function of the angle of rotation of $-\mathrm{CH}_{2} \mathrm{OH}$ subunit around $\mathrm{C} 1-\mathrm{C} 2$ bond for 2,2-dimethylbutan-1-ol (a) and of rotation of $-\mathrm{CH}\left(\mathrm{CH}_{3}\right)_{2}$ around $\mathrm{C} 2-\mathrm{C} 3$ bond for 2,3-dimethylbutan$-2-\mathrm{ol}(\mathrm{b})$.
2,3-DM-2-B) around $\mathrm{C} 1-\mathrm{C} 2$ bond and rotation of the $-\mathrm{CH}\left(\mathrm{CH}_{3}\right)_{2}$ around $\mathrm{C} 2-\mathrm{C} 3$ bond for 2,3-DM-2-B have been calculated by the PM3 method, as less time consuming, and we have obtained three rotational conformations: trans, gauche $(-)$ and gauche $(+)$. The height of the potential energy barrier between trans - gauche $(+)$ and gauche $(+)-$ gauche $(-)$ conformations is $3 \mathrm{kcal} / \mathrm{mol}$ and $2.8 \mathrm{kcal} / \mathrm{mol}$ for $2,2-\mathrm{DM}-1 \mathrm{~B}$, while 4.1 and 4.0 for 2,3-DM-2 B, respectively, as shown in Fig. 2.

Optimised geometry of 2,2-dimethylbutan-1-ol and 2,3-dimethylbutan-2-ol molecules.

\begin{tabular}{|c|c|c|c|c|c|c|c|c|c|}
\hline \multicolumn{5}{|c|}{ 2,2-dimethylbutan-1-ol } & \multicolumn{5}{|c|}{ 2,3-dimethylbutan-2-ol } \\
\hline \multirow{4}{*}{$\begin{array}{l}\text { Internal } \\
\text { bond }\end{array}$} & \multirow{2}{*}{\multicolumn{4}{|c|}{$\begin{array}{c}\text { Bond length }[\AA] \\
\text { Isolated molecule }\end{array}$}} & & \multirow{2}{*}{\multicolumn{4}{|c|}{$\begin{array}{l}\text { Bond length }[\AA] \\
\text { Isolated molecule }\end{array}$}} \\
\hline & & & & & & & & & \\
\hline & \multicolumn{2}{|c|}{$\mathrm{DFT} / \mathrm{B} 3 \mathrm{LYP} / 6-311 \mathrm{G}^{* *}$} & \multicolumn{2}{|c|}{ PM3 } & & \multicolumn{2}{|c|}{ DFT/B3LYP/6-311G** } & \multicolumn{2}{|c|}{ PM3 } \\
\hline & trans & gauche & trans & gauche & & trans & gauche & trans & gauche \\
\hline $\mathrm{H}-\mathrm{O}$ & 0.96107 & 0.96154 & 0.94994 & 0.94968 & $\mathrm{O}-\mathrm{H}$ & 0.96246 & 0.96268 & 0.94970 & 0.94999 \\
\hline $\mathrm{H}-\mathrm{O}$ & 0.96107 & 0.96154 & 0.94994 & 0.94968 & $\mathrm{O}-\mathrm{H}$ & 0.96246 & 0.96268 & 0.94970 & 0.94999 \\
\hline $\mathrm{C} 1-\mathrm{C} 2$ & 1.53902 & 1.54644 & 1.52572 & 1.52510 & $\mathrm{C} 1-\mathrm{C} 2$ & 1.53710 & 1.53619 & 1.52379 & 1.52436 \\
\hline $\mathrm{C} 2-\mathrm{C} 3$ & 1.54969 & 1.54946 & 1.52832 & 1.52866 & $\mathrm{C} 2-\mathrm{C} 3$ & 1.55701 & 1.55419 & 1.53082 & 1.53124 \\
\hline $\mathrm{C} 3-\mathrm{C} 4$ & 1.53266 & 1.53271 & 1.52281 & 1.52284 & $\mathrm{C} 3-\mathrm{C} 4$ & 1.53782 & 1.53617 & 1.52405 & 1.52353 \\
\hline $\mathrm{C} 2-\mathrm{C} 5$ & 1.54001 & 1.54016 & 1.52466 & 1.52424 & & 1.53710 & 1.53569 & 1.52359 & 1.52332 \\
\hline $\mathrm{C} 2-\mathrm{C} 6$ & 1.54000 & 1.53861 & 1.52497 & 1.52447 & $\mathrm{C} 3-\mathrm{C} 6$ & 1.53782 & 1.53550 & 1.52396 & 1.52430 \\
\hline \multirow{3}{*}{$\begin{array}{l}\text { Internal } \\
\text { bond }\end{array}$} & \multicolumn{4}{|c|}{$\begin{array}{c}\text { Internal angles [degree] } \\
\text { Isolated molecule }\end{array}$} & & \multicolumn{4}{|c|}{$\begin{array}{c}\text { Internal angles [degree] } \\
\text { Isolated molecule }\end{array}$} \\
\hline & \multicolumn{2}{|c|}{ DFT/B3LYP/6-311G** } & \multicolumn{2}{|c|}{ PM3 } & & \multicolumn{2}{|c|}{ DFT/B3LYP/6-311G** } & \multicolumn{2}{|c|}{ PM3 } \\
\hline & trans & gauche & trans & gauche & & trans & gauche & trans & gauche \\
\hline $\mathrm{H}-\mathrm{O}-\mathrm{C} 1$ & 108.165 & 108.019 & 109.484 & 109.603 & $\mathrm{H}-\mathrm{O}-\mathrm{C} 2$ & 107.850 & 107.739 & 109.524 & 109.529 \\
\hline $\mathrm{O}-\mathrm{C} 1-\mathrm{C} 2$ & 109.590 & 108.019 & 111.151 & 110.804 & $\mathrm{O}-\mathrm{C} 2-\mathrm{C} 1$ & 109.265 & 108.286 & 108.387 & 108.240 \\
\hline $\mathrm{C} 1-\mathrm{C} 2-\mathrm{C} 3$ & 106.679 & 108.204 & 107.554 & 108.851 & $\mathrm{O}-\mathrm{C} 2-\mathrm{C} 5$ & 111.265 & 109.138 & 108.774 & 108.411 \\
\hline $\mathrm{C} 2-\mathrm{C} 3-\mathrm{C} 4$ & 116.410 & 116.704 & 113.072 & 112.830 & $\mathrm{O}-\mathrm{C} 2-\mathrm{C} 3$ & 105.613 & 103.970 & 110.434 & 107.778 \\
\hline $\mathrm{C} 1-\mathrm{C} 2-\mathrm{C} 5$ & 108.934 & 109.133 & 109.120 & 109.119 & $\mathrm{C} 1-\mathrm{C} 2-\mathrm{C} 3$ & 111.695 & 111.387 & 110.646 & 112.462 \\
\hline $\mathrm{C} 1-\mathrm{C} 2-\mathrm{C} 6$ & 108.927 & 107.368 & 109.499 & 108.189 & $\mathrm{C} 1-\mathrm{C} 2-\mathrm{C} 5$ & 109.213 & 110.313 & 108.198 & 109.058 \\
\hline $\mathrm{C} 3-\mathrm{C} 2-\mathrm{C} 5$ & 111.118 & 111.311 & 110.687 & 110.655 & $\mathrm{C} 2-\mathrm{C} 3-\mathrm{C} 4$ & 112.411 & 112.638 & 111.150 & 111.202 \\
\hline $\mathrm{C} 3-\mathrm{C} 2-\mathrm{C} 6$ & 111.119 & 111.145 & 110.393 & 110.730 & $\mathrm{C} 2-\mathrm{C} 3-\mathrm{C} 6$ & 112.411 & 113.754 & 111.297 & 112.469 \\
\hline $\mathrm{C} 5-\mathrm{C} 2-\mathrm{C} 6$ & 109.964 & 109.570 & 109.550 & 109.244 & $\mathrm{C} 4-\mathrm{C} 3-\mathrm{C} 6$ & 109.543 & 110.491 & 108.428 & 108.945 \\
\hline & & & & & $\mathrm{C} 3-\mathrm{C} 2-\mathrm{C} 5$ & 111.695 & 113.430 & 110.334 & 110.749 \\
\hline
\end{tabular}

Figure 3a presents the low temperature $G_{\exp }(\nu)$ phonon density of states spectra of crystal and glass of ODIC phase of 2,2-DM-1-B together with the calculated ones in isolated molecule approximation for trans (upper part) and gauche (lower part) conformation, respectively. An excess of vibrational density of states is evidenced for the glassy phase (GC2) with respect to the well-ordered crystals (C3). It is in agreement with the results reported earlier [24-26]. Moreover, the $G(\nu) \sim \nu^{2}$ behaviour observed for ordered crystal is consistent with the Debye theory for dynamics of crystal lattice, while the linear frequency dependence of density of states $G(\nu) \sim \nu$ as received in glass of ODIC phase.

In Fig. 3b the calculated $G_{\text {cal }}(\nu)$ spectra for two conformations (trans and gauche type) of isolated molecule are shown together with the experimental phonon density of states spectra of crystalline sample of the 2,3-DM-2-B. In Table II the frequencies of vibrational normal modes calculated in isolated molecule approximation of 2,2-DM-1-B and 2,3-DM-2-B are compared with the experimen- 


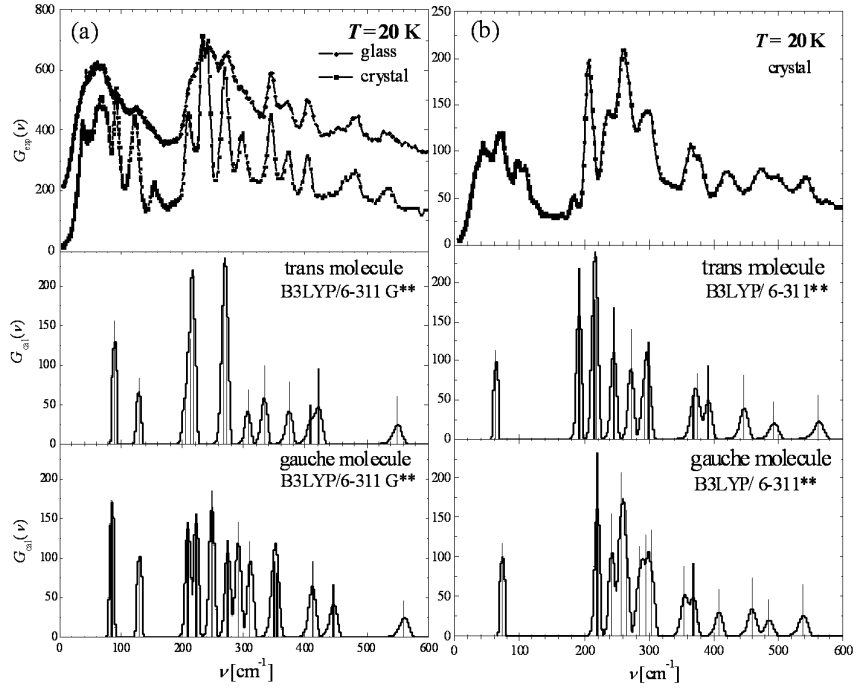

Fig. 3. Comparison of the experimental IINS low-temperature phonon density of states $G_{\exp }(\nu)$ of crystal and glass of ODIC phase for 2,2-dimethylbutan-1-ol and of crystal phase for 2,3-dimethylbutan-2-ol with $G_{\text {cal }}(\nu)$ calculated by DFT method using the B3LYP $/ 6-311 \mathrm{G}^{* *}$ level. For both alcohols we compare two conformations (trans and gauche) of molecules.

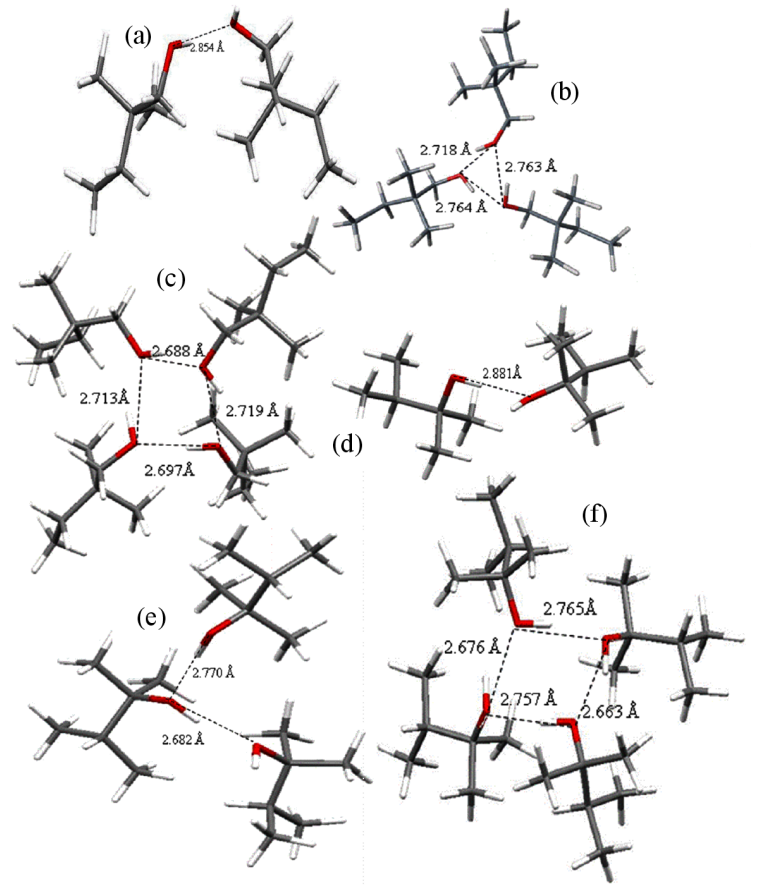

Fig. 4. Geometry of the lowest energy conformers in clusters: dimer (a), trimer (b), tetramer (c) of 2,2-dimethylbutan-1-ol and dimer (d), trimer (e), tetramer (f) of 2,3-dimethylbutan-2-ol.

tal ones obtained by the neutron $G(\nu)$ at $20 \mathrm{~K}$ and IR at $290 \mathrm{~K}$ spectroscopes. In lower part of Figs. 5-8 the calculated phonon density of state spectra $G(\nu)$ and IR absorption for 2,2-DM-1-B and 2,3-DM-2B, respectively, are presented . Moreover, in upper part of these figures

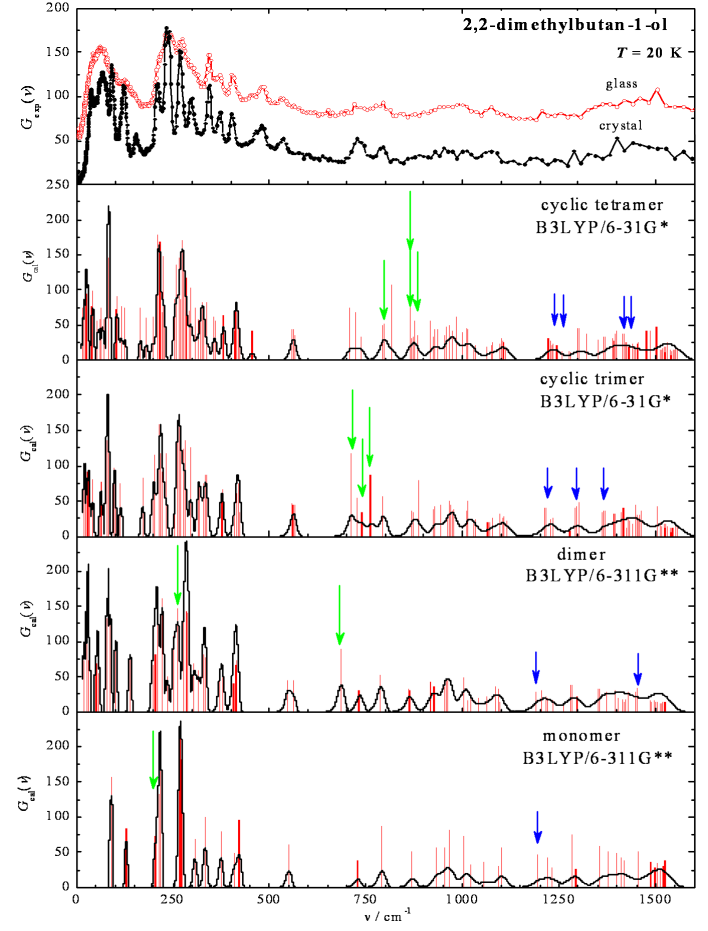

Fig. 5. The comparison of experimental and calculated phonon density of states spectra for 2,2-dimethylbutan-1-ol. The frequencies of out-of-plane $\gamma[\mathrm{O}-\mathrm{H} . . . \mathrm{O}]$ bands are marked with green arrows, while of in-plane $\delta[\mathrm{O}-\mathrm{H} . . . \mathrm{O}]$ bands with blue arrows. The calculated frequencies of density of states $G_{\text {cal }}(\nu)$ (marked by columns bars) and the spectra including resolution function of the NERA-PR spectrometer (solid lines) for 2,2-dimethylbutan-1-ol.

there were shown the appropriate experimental spectra. Both studied isomers of dimethylbutanol have 57 normal vibrational modes, namely 6 torsional out-of-plane, 31 deformational in-plane and 20 stretching.

For 2,2-DM-1-B the torsional out-of-plane $\chi[\mathrm{C}-\mathrm{C}]$ of methyl's as well as (one) $\chi[\mathrm{C}-\mathrm{O}]$ modes, identified using the B3LYP/6-311G** (PM3) method of calculations were localized between $85 \mathrm{~cm}^{-1}$ and $273.7 \mathrm{~cm}^{-1}$ (and by the PM3 at $93.5 \mathrm{~cm}^{-1}$ and $250.5 \mathrm{~cm}^{-1}$ ). In the IINS experimental spectra the strong bands described mainly as out-of plane torsion of methyl group appear (in $\mathrm{cm}^{-1}$ ) at 92 , 121.3, 153.8, 209, 231, 240, 267.1 and 296, among them the ones at 92 and $121.3 \mathrm{~cm}^{-1}$ are lying in the lattice branch. The band at the lowest value of energy transfer are assigned as out-of-plane torsion of $\left(\mathrm{CH}_{3}\right)_{3} \mathrm{CH}_{2}$ group. The modes assigned as out-of-plane torsion of methyl group are very weak in IR spectra while they are strong in neutron spectroscopy.

The deformational in-plane $\delta\left[\mathrm{C}-\mathrm{C}-\mathrm{C}_{\mathrm{m}}\right]$ modes, where the $\mathrm{C}_{\mathrm{m}}$ atom belongs to a methyl group (i.e., C3, C5, C6, notation as in Fig. 1a,b), were predicted in the range from 310.8 to $560.4 \mathrm{~cm}^{-1}$ (330.9 to $577.4 \mathrm{~cm}^{-1}$ by the PM3) and appear in $G(\nu)$ in the range from 342 to 


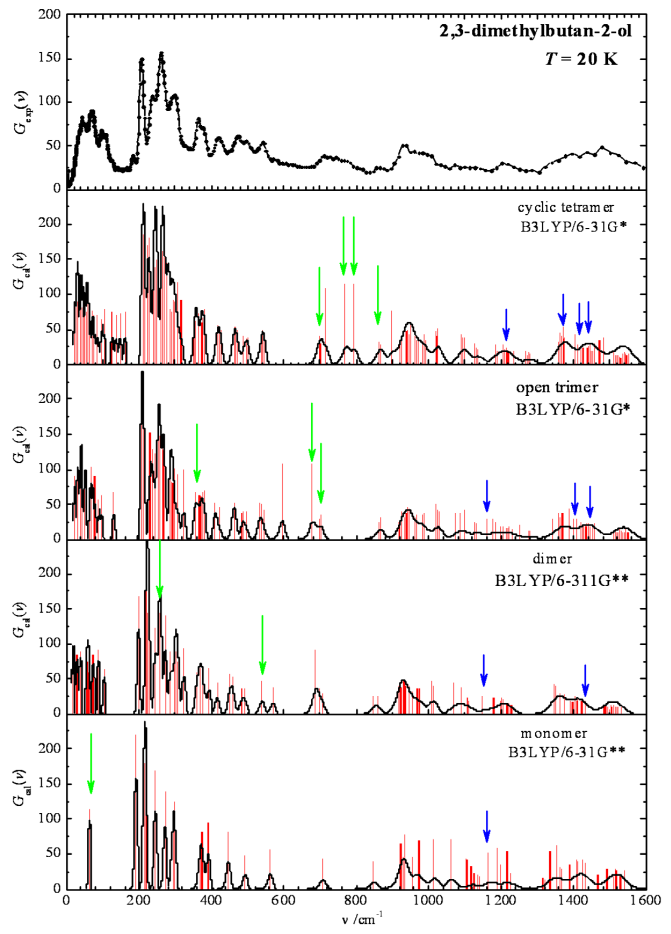

Fig. 6. As in Fig. 5, but for 2,3-dimethylbutan-2-ol.

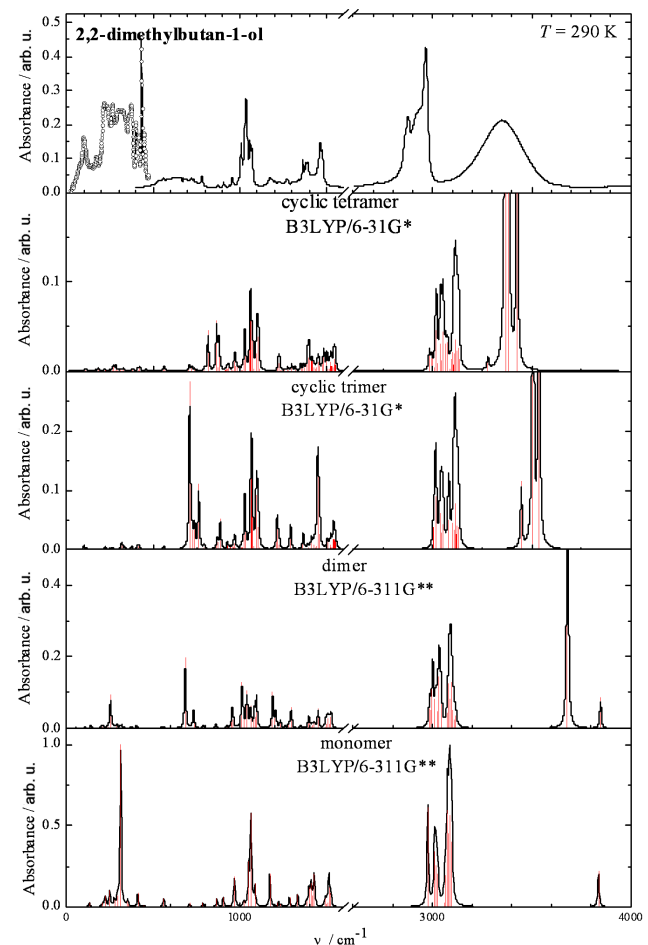

Fig. 7. The comparison of experimental and calculated infrared absorption spectra for 2,2-dimethylbutan-1-ol In high frequency range the red shift of stretching vibrations is visible. The most intensive bands correspond with blue shifting of deformational $\mathrm{COH}$ modes.

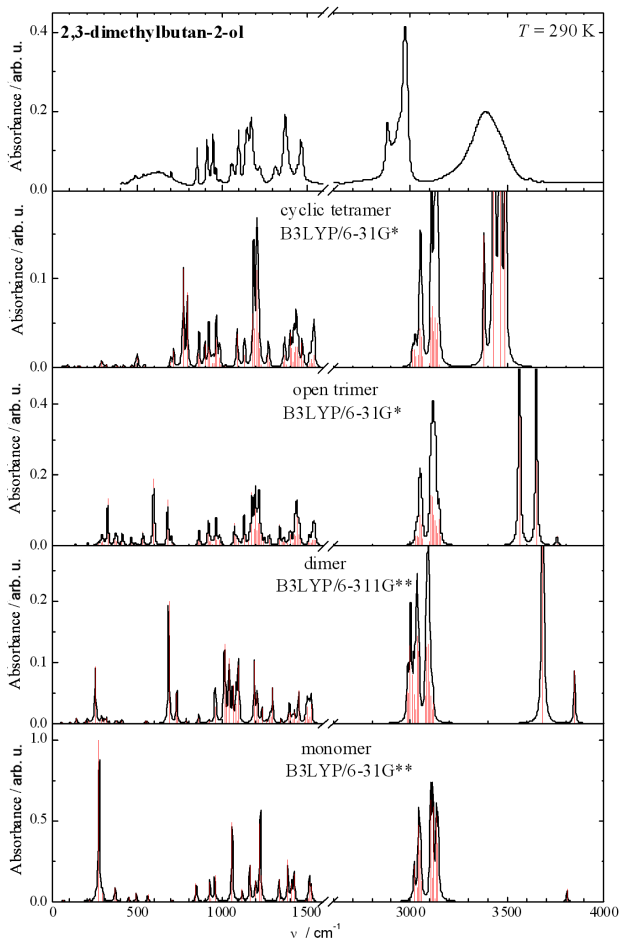

Fig. 8. As in Fig 7, but for 2,3-dimethylbutan-2-ol.

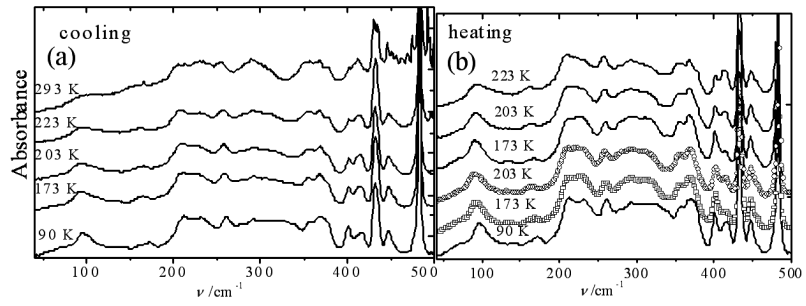

Fig. 9. Far-infrared spectrum of 2,2-dimethylbutan-1-ol measured during cooling (a) and heating (b).

$642 \mathrm{~cm}^{-1}$ in the IINS spectra. The bands at 344,370 and $401 \mathrm{~cm}^{-1}$ are strong because they are accompanied by the in-plane motion of methyl. The stretching modes of the $\nu\left[\mathrm{C} 2-\mathrm{C}_{\mathrm{m}}\right]$ type were predicted at 787.7 or $789.8 \mathrm{~cm}^{-1}$ $\left(836.3 \mathrm{~cm}^{-1}\right.$ by the PM3) and were observed at $793 \mathrm{~cm}^{-1}$ in experimental $G(\nu)$ spectra at $20 \mathrm{~K}$, as well as in IR spectra at room temperature at $782.1 \mathrm{~cm}^{-1}$.

The DFT (PM3) calculations give the position of deformational in-plane $\delta\left[\mathrm{C}-\mathrm{C}_{\mathrm{m}}-\mathrm{H}_{\mathrm{m}}\right]$ modes in the range from 953 to $1054.5 \mathrm{~cm}^{-1}$ (from 941.2 to $1020 \mathrm{~cm}^{-1}$ ). In $G(\nu)$ spectra they are at $929,951.5$, and $1010 \mathrm{~cm}^{-1}$, while in IR at $938.4,956.7,993.3$, and $1008.8 \mathrm{~cm}^{-1}$, respectively.

The symmetric and asymmetric stretching $\nu\left[\mathrm{C}_{\mathrm{m}}-\mathrm{H}_{\mathrm{m}}\right]$ modes of methyl groups were identified by the DFT (PM3) method between 3026.6 and $3115.4 \mathrm{~cm}^{-1}$ (2936.1 and $3057.6 \mathrm{~cm}^{-1}$ ) and in the MIR spectra the broad band was observed close to $2721,2873.7,2964.1 \mathrm{~cm}^{-1}$. 
TABLE II

Experimental frequencies of MIR and $G_{\exp }(\nu)$ results for 2,2-dimethylbutan-1-ol and of FIR, MIR and $G_{\exp }(\nu)$ results for 2,3-dimethylbutan-2-ol and calculated frequencies for isolated molecules.

\begin{tabular}{|c|c|c|c|c|c|c|c|c|c|c|c|}
\hline \multicolumn{5}{|c|}{ 2,2-dimethylbutan-1-ol } & \multicolumn{6}{|c|}{ 2,3-dimethylbutan-2-ol } & \multirow{3}{*}{$\begin{array}{c}\text { Assignment and } \\
\text { and PED [\%] }>10 \%\end{array}$} \\
\hline Experin & nental & & Salculate & & \multirow{2}{*}{$\begin{array}{l}\text { Assignment and } \\
\text { PED [\%] > } 10 \%\end{array}$} & \multirow{2}{*}{\multicolumn{5}{|c|}{ frequencies $\left[\mathrm{cm}^{-1}\right]$}} & \\
\hline \multicolumn{5}{|c|}{ frequencies $\left[\mathrm{cm}^{-1}\right]$} & & & & & & & \\
\hline \multirow[t]{3}{*}{$\begin{array}{l}\text { FIR } 90 \mathrm{~K} / \\
\text { MIR } 290 \mathrm{~K} \\
\end{array}$} & $\begin{array}{c}G_{\exp }(\nu) \\
20 \mathrm{~K}\end{array}$ & \multicolumn{2}{|c|}{\begin{tabular}{|c|}
$\mathrm{B} 3 \mathrm{LYP} /$ \\
$6-311 \mathrm{G}^{* *}$ \\
\end{tabular}} & \multirow[t]{2}{*}{ PM3 } & & \multirow[t]{2}{*}{ MIR $290 \mathrm{~K}$} & \multirow[t]{2}{*}{$\begin{array}{c}G_{\exp }(\nu) \\
20 \mathrm{~K} \\
\end{array}$} & \multicolumn{2}{|c|}{$\begin{array}{c}\mathrm{B} 3 \mathrm{LYP} / \\
6-311 \mathrm{G}^{* *}\end{array}$} & \multirow[t]{2}{*}{ PM3 } & \\
\hline & & trans & gauche & & - & & & trans & gauche & & \\
\hline & $92.0 \pm 1$ & 89.7 & 85.0 & 93.5 & $\chi[\mathrm{C} 1-\mathrm{C} 2] 78 \%$ & & $\begin{array}{l}107.7 \pm 1 \\
123.4 \pm 1\end{array}$ & 65.8 & 73 & 102.3 & $\chi[\mathrm{C} 2-\mathrm{C} 3] 82 \%$ \\
\hline \multirow[t]{2}{*}{96} & & & & & $\sigma[\mathrm{O}-\mathrm{H} \ldots \mathrm{O}]$ & & & & & & \\
\hline & $121.3 \pm 1$ & 129.0 & 130.0 & 116.7 & $\begin{array}{l}\chi[\mathrm{C} 2-\mathrm{C} 3] \\
\chi 3 \% \\
\chi[\mathrm{C} 2-\mathrm{C} 6] \\
10 \%\end{array}$ & & & 193.1 & 218.6 & 170.8 & $\begin{array}{l}\chi[\mathrm{C} 2-\mathrm{C} 1] 29 \% \\
\chi[\mathrm{C} 2-\mathrm{C} 5] \\
\chi \\
\chi[\mathrm{C} 3-\mathrm{C} 4] \\
\chi[\mathrm{C} 3-\mathrm{C} 6] \\
20 \% \\
20 \%\end{array}$ \\
\hline 171 & $\begin{array}{c}153.8 \pm 1 \\
209 \pm 1\end{array}$ & 205.0 & 208.9 & 157.4 & 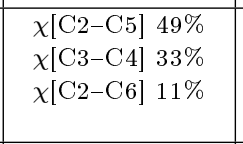 & & $182.3 \pm 1$ & 214.9 & 241.9 & 190.1 & $\begin{array}{l}\chi[\mathrm{C} 3-\mathrm{C} 6] 25 \% \\
\chi[\mathrm{C} 3-\mathrm{C} 4] 25 \% \\
\chi[\mathrm{C} 2-\mathrm{C} 5] 24 \% \\
\chi[\mathrm{C} 2-\mathrm{C} 1] 24 \% \\
\end{array}$ \\
\hline 212 & & & & & $\chi[\mathrm{O}-\mathrm{H}]$ & & $205.2 \pm 1$ & 217.2 & 253.9 & 201.9 & $\chi[\mathrm{C} 3-\mathrm{C} 6] 21 \%$ \\
\hline \multirow[t]{2}{*}{232} & $\begin{array}{l}231 \pm 1 \\
240 \pm 1\end{array}$ & 213.1 & 222.5 & 187.3 & $\begin{array}{l}\chi[\mathrm{C} 2-\mathrm{C} 6] 50 \% \\
\chi[\mathrm{C} 2-\mathrm{C} 5] 29 \%\end{array}$ & & & & & & 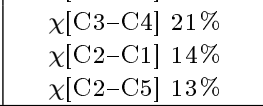 \\
\hline & & 218.4 & 248.1 & 213.3 & $\begin{array}{c}\chi[\mathrm{C} 3-\mathrm{C} 4] 25 \% \\
\delta[\mathrm{C} 1-\mathrm{C} 2-\mathrm{C} 3] 23 \% \\
\chi[\mathrm{C} 2-\mathrm{C} 6] 10 \%\end{array}$ & & $235.1 \pm 1$ & 247.7 & 262.9 & 241.9 & $\begin{array}{l}\chi[\mathrm{C} 2-\mathrm{C} 1] 22 \% \\
\chi[\mathrm{C} 2-\mathrm{C} 5] 21 \% \\
\chi[\mathrm{C} 3-\mathrm{C} 6] 17 \% \\
\chi[\mathrm{C} 3-\mathrm{C} 4] 17 \% \\
\end{array}$ \\
\hline $\begin{array}{l}260 \\
278\end{array}$ & $267.1 \pm 1$ & 267.9 & 273.7 & 250.5 & $\begin{array}{c}\chi[\mathrm{C} 3-\mathrm{C} 4] 28 \% \\
\chi[\mathrm{C} 2-\mathrm{C} 5] 15 \% \\
\delta[\mathrm{C} 1-\mathrm{C} 2-\mathrm{C} 5] 14 \% \\
\delta[\mathrm{C} 1-\mathrm{C} 2-\mathrm{C} 3] 10 \%\end{array}$ & & $261.2 \pm 1$ & 291.2 & 283.6 & 273 & 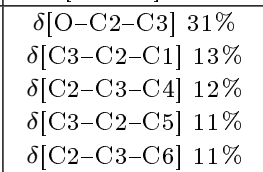 \\
\hline 293 & $296.0 \pm 2$ & 271.9 & 290.7 & 285.4 & $\chi[\mathrm{O}-\mathrm{C} 1] 79 \%$ & & $297.9 \pm 2$ & 291.3 & 290.7 & 277.8 & $\begin{array}{c}\chi[\mathrm{O}-\mathrm{C} 2] 71 \% \\
\delta[\mathrm{O}-\mathrm{C} 2-\mathrm{C} 1] 10 \% \\
\end{array}$ \\
\hline $\begin{array}{l}320 \\
340\end{array}$ & $344 \pm 2$ & 306.8 & 310.8 & 330.9 & $\begin{array}{l}\delta[\mathrm{C} 3-\mathrm{C} 2-\mathrm{C} 6] 30 \% \\
\delta[\mathrm{C} 1-\mathrm{C} 2-\mathrm{C} 6] 26 \% \\
\delta[\mathrm{C} 3-\mathrm{C} 2-\mathrm{C} 5] 14 \%\end{array}$ & & $364.0 \pm 2$ & 304.8 & 299.2 & 358.3 & $\begin{array}{l}\delta[\mathrm{C} 3-\mathrm{C} 2-\mathrm{C} 1] 27 \% \\
\delta[\mathrm{C} 3-\mathrm{C} 2-\mathrm{C} 5] 27 \% \\
\delta[\mathrm{O}-\mathrm{C} 2-\mathrm{C} 1] 14 \% \\
\delta[\mathrm{O}-\mathrm{C} 2-\mathrm{C} 5] 13 \% \\
\end{array}$ \\
\hline $\begin{array}{l}358 \\
371\end{array}$ & $370 \pm 3$ & 333.7 & 349.1 & 372.8 & \begin{tabular}{|c|}
$\delta[\mathrm{C} 3-\mathrm{C} 2-\mathrm{C} 5] 30 \%$ \\
$\delta[\mathrm{O}-\mathrm{C} 1-\mathrm{C} 2] 20 \%$ \\
$\delta[\mathrm{C} 5-\mathrm{C} 2-\mathrm{C} 6] \quad 19 \%$
\end{tabular} & & $375.9 \pm 3$ & \begin{tabular}{|l|}
368.7 \\
\end{tabular} & 353.8 & 406.0 & $\begin{array}{c}\delta[\mathrm{C} 5-\mathrm{C} 2-\mathrm{C} 1] 45 \% \\
\delta[\mathrm{C} 4-\mathrm{C} 3-\mathrm{C} 6] 24 \% \\
\delta[\mathrm{O}-\mathrm{C} 2-\mathrm{C} 5] 10 \% \\
\delta[\mathrm{O}-\mathrm{C} 2-\mathrm{C} 1] 10 \%\end{array}$ \\
\hline $\begin{array}{c}401 \\
418.5\end{array}$ & $401 \pm 3$ & 374.1 & 354.1 & 420.4 & $\begin{array}{l}\delta[\mathrm{C} 1-\mathrm{C} 2-\mathrm{C} 5] 30 \% \\
\delta[\mathrm{C} 5-\mathrm{C} 2-\mathrm{C} 6] 29 \% \\
\delta[\mathrm{C} 2-\mathrm{C} 3-\mathrm{C} 4] 21 \%\end{array}$ & $\begin{array}{l}414.7 \\
449.4 \\
464.8\end{array}$ & $418.4 \pm 3$ & 375.5 & 367.1 & 413.2 & $\begin{array}{l}\delta[\mathrm{C} 2-\mathrm{C} 3-\mathrm{C} 4] 36 \% \\
\delta[\mathrm{C} 2-\mathrm{C} 3-\mathrm{C} 6] 35 \%\end{array}$ \\
\hline 434 & & 408.4 & 411.5 & 439.3 & 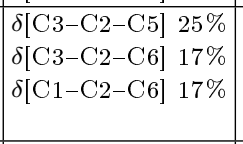 & & & 392.8 & 408.8 & 451.4 & $\begin{array}{l}\delta[\mathrm{C} 5-\mathrm{C} 2-\mathrm{C} 1] 20 \% \\
\delta[\mathrm{C} 4-\mathrm{C} 3-\mathrm{C} 6] 18 \% \\
\delta[\mathrm{C} 3-\mathrm{C} 2-\mathrm{C} 5] 12 \% \\
\delta[\mathrm{C} 3-\mathrm{C} 2-\mathrm{C} 1] 11 \% \\
\end{array}$ \\
\hline $\begin{array}{l}447 \\
483\end{array}$ & $\begin{array}{l}464 \pm 4 \\
481 \pm 4\end{array}$ & 421.7 & 445.6 & 444.4 & 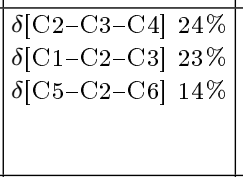 & 488.2 & $472.0 \pm 4$ & 446.5 & 458.3 & 483.98 & $\begin{array}{l}\delta[\mathrm{C} 4-\mathrm{C} 3-\mathrm{C} 6] 28 \% \\
\delta[\mathrm{C} 3-\mathrm{C} 2-\mathrm{C} 5] 15 \% \\
\delta[\mathrm{C} 3-\mathrm{C} 2-\mathrm{C} 1] 15 \% \\
\delta[\mathrm{O}-\mathrm{C} 2-\mathrm{C} 1] 12 \% \\
\delta[\mathrm{O}-\mathrm{C} 2-\mathrm{C} 5] 12 \% \\
\end{array}$ \\
\hline $\begin{array}{c}529.5 \pm 1 \\
562.2 \\
642.3\end{array}$ & $\begin{array}{l}536 \pm 5 \\
637 \pm 5\end{array}$ & 549.9 & 560.4 & 577.4 & $\begin{array}{c}\delta[\mathrm{O}-\mathrm{C} 1-\mathrm{C} 2] 22 \% \\
\delta[\mathrm{C} 2-\mathrm{C} 3-\mathrm{C} 4] 22 \% \\
\delta[\mathrm{C} 3-\mathrm{C} 2-\mathrm{C} 5] 12 \%\end{array}$ & $\begin{array}{l}537.0 \\
618.2\end{array}$ & $\begin{array}{r}497.9 \pm 5 \\
540.6 . \pm 5\end{array}$ & 493.6 & 484.3 & 528.0 & $\begin{array}{l}\delta[\mathrm{O}-\mathrm{C} 2-\mathrm{C} 5] 20 \% \\
\delta[\mathrm{O}-\mathrm{C} 2-\mathrm{C} 1] 20 \% \\
\delta[\mathrm{C} 3-\mathrm{C} 2-\mathrm{C} 1] 14 \% \\
\delta[\mathrm{C} 3-\mathrm{C} 2-\mathrm{C} 5] 14 \% \\
\end{array}$ \\
\hline $\begin{array}{l}721.4 \\
733.9\end{array}$ & $728 \pm 8$ & 727.7 & 709.1 & 806.4 & 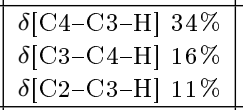 & 700.2 & $711.9 \pm 8$ & 563.6 & 537.1 & 579.9 & $\begin{array}{c}\delta[\mathrm{O}-\mathrm{C} 2-\mathrm{C} 3] 31 \% \\
\delta[\mathrm{C} 2-\mathrm{C} 3-\mathrm{C} 6] 13 \% \\
\delta[\mathrm{C} 2-\mathrm{C} 3-\mathrm{C} 4] 13 \% \\
\end{array}$ \\
\hline 782.1 & $793 \pm 9$ & 789.9 & 787.7 & 836.3 & $\begin{array}{l}\nu[\mathrm{C} 2-\mathrm{C} 3] 22 \% \\
\nu[\mathrm{C} 2-\mathrm{C} 5] 20 \% \\
\nu[\mathrm{C} 1-\mathrm{C} 2] 17 \% \\
\nu[\mathrm{C} 2-\mathrm{C} 6] 11 \% \\
\end{array}$ & & $\begin{array}{l}730.3 \pm 9 \\
775.0 \pm 9\end{array}$ & 704.2 & 695.3 & 789.3 & $\nu[\mathrm{C} 2-\mathrm{C} 3] 50 \%$ \\
\hline $\begin{array}{l}865.1 \\
875.7\end{array}$ & $887 \pm 10$ & 867.8 & 867.9 & 885.8 & $\begin{array}{c}\delta[\mathrm{H}-\mathrm{C} 1-\mathrm{C} 2] 43 \% \\
\delta[\mathrm{O}-\mathrm{C} 1-\mathrm{H}] 10 \%\end{array}$ & 853.5 & $865.7 \pm 10$ & 844.7 & 855.9 & 928.4 & $\begin{array}{c}\nu[\mathrm{C} 2-\mathrm{C} 5] 19 \% \\
\nu[\mathrm{C} 2-\mathrm{C} 1] 19 \% \\
\nu[\mathrm{O}-\mathrm{C} 2] 15 \%\end{array}$ \\
\hline
\end{tabular}


TABLE II (cont.)

\begin{tabular}{|c|c|c|c|c|c|c|c|c|c|c|c|}
\hline 904.6 & & 931.3 & 903.3 & 906.0 & $\begin{array}{c}\nu[\mathrm{C} 1-\mathrm{C} 2] 31 \% \\
\nu[\mathrm{C} 2-\mathrm{C} 3] 18 \% \\
\delta[\mathrm{C} 2-\mathrm{C} 6-\mathrm{H}] 20 \% \\
\end{array}$ & 911.4 & $927.6 \pm 10$ & 920.5 & 917.9 & 933.7 & $\begin{array}{l}\delta[\mathrm{C} 3-\mathrm{C} 6-\mathrm{H}] 26 \% \\
\delta[\mathrm{C} 3-\mathrm{C} 4-\mathrm{H}] 26 \%\end{array}$ \\
\hline 938.4 & $929 \pm 10$ & 953.6 & 941.4 & 941.2 & $\begin{array}{l}\delta[\mathrm{C} 2-\mathrm{C} 6-\mathrm{H}] \quad 40 \% \\
\delta[\mathrm{C} 2-\mathrm{C} 5-\mathrm{H}] \quad 35 \%\end{array}$ & & & 922.2 & 922.1 & 939.8 & $\begin{array}{l}\delta[\mathrm{C} 2-\mathrm{C} 5-\mathrm{H}] 32 \% \\
\delta[\mathrm{C} 2-\mathrm{C} 1-\mathrm{H}] 32 \%\end{array}$ \\
\hline 956.7 & $951.5 \pm 10$ & 965.8 & 969.2 & 952.6 & $\begin{array}{c}\delta[\mathrm{C} 2-\mathrm{C} 5-\mathrm{H}] 22 \% \\
\delta[\mathrm{C} 2-\mathrm{C} 6-\mathrm{H}] 16 \% \\
\nu[\mathrm{C} 2-\mathrm{C} 6] 13 \% \\
\nu[\mathrm{C} 2-\mathrm{C} 5] 13 \%\end{array}$ & 945.1 & & 932.3 & 935.2 & 964.0 & $\begin{array}{c}\nu[\mathrm{O}-\mathrm{C} 2] 20 \% \\
\delta[\mathrm{C} 2-\mathrm{C} 5-\mathrm{H}] 15 \% \\
\delta[\mathrm{C} 2-\mathrm{C} 1-\mathrm{H}] 15 \%\end{array}$ \\
\hline 993.3 & & 1003.6 & 998.4 & 983.7 & 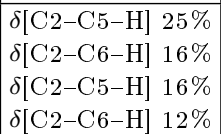 & 963.4 & $958 \pm 10$ & 946.9 & 949.3 & 966.7 & $\begin{array}{l}\delta[\mathrm{C} 3-\mathrm{C} 6-\mathrm{H}] 14 \% \\
\delta[\mathrm{C} 3-\mathrm{C} 4-\mathrm{H}] 14 \%\end{array}$ \\
\hline \multirow[t]{2}{*}{1008.8} & $1010 \pm 10$ & 1020.9 & 1024.1 & 1010.5 & $\begin{array}{l}\delta[\mathrm{C} 2-\mathrm{C} 3-\mathrm{H}] 45 \% \\
\delta[\mathrm{C} 3-\mathrm{C} 4-\mathrm{H}] 16 \% \\
\end{array}$ & 989.5 & $984 \pm 10$ & 968.7 & 975.2 & 982.5 & $\begin{array}{l}\delta[\mathrm{C} 2-\mathrm{C} 5-\mathrm{H}] 22 \% \\
\delta[\mathrm{C} 2-\mathrm{C} 1-\mathrm{H}] 22 \%\end{array}$ \\
\hline & & 1054.5 & 1052.8 & 1020.0 & $\delta[\mathrm{C} 3-\mathrm{C} 4-\mathrm{H}] 32 \%$ & 1056.0 & & 1010.1 & 1004.7 & 996.2 & $\begin{array}{l}\nu[\mathrm{C} 3-\mathrm{C} 6] 13 \% \\
\nu[\mathrm{C} 3-\mathrm{C} 4] 13 \%\end{array}$ \\
\hline $\begin{array}{l}1035.8 \\
1059.9\end{array}$ & & 1092.8 & 1065.9 & 1035.0 & $\begin{array}{c}\delta[\mathrm{O}-\mathrm{C} 1-\mathrm{H}] 47 \% \\
\delta[\mathrm{H}-\mathrm{C} 1-\mathrm{C} 2] 30 \%\end{array}$ & 1064.7 & $1072 \pm 15$ & 1061.4 & 1086.5 & 1034.7 & 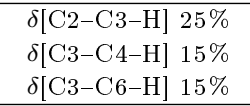 \\
\hline 1070.5 & $1074 \pm 13$ & 1100.9 & 1087.9 & 1100.4 & $\begin{array}{c}\delta[\mathrm{C} 4-\mathrm{C} 3-\mathrm{H}] 18 \% \\
\nu[\mathrm{C} 3-\mathrm{C} 4] 17 \% \\
\delta[\mathrm{O}-\mathrm{C} 1-\mathrm{H}] 11 \% \\
\end{array}$ & 1099.4 & & 1111.4 & 1104.3 & 1088.7 & $\begin{array}{l}\delta[\mathrm{H}-\mathrm{C} 3-\mathrm{C} 4] 33 \% \\
\delta[\mathrm{H}-\mathrm{C} 3-\mathrm{C} 6] 33 \%\end{array}$ \\
\hline \multirow[t]{3}{*}{1179.5} & $\begin{array}{l}1129 \pm 15 \\
1189 \pm 15\end{array}$ & 1194.9 & 1174.0 & 1113.4 & 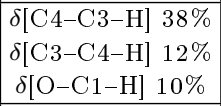 & 1147.6 & & 1160.9 & 1146.0 & 1125.1 & $\begin{array}{c}\delta[\mathrm{H}-\mathrm{C} 3-\mathrm{C} 6] 14.45 \% \\
\delta[\mathrm{H} 1-\mathrm{O}-\mathrm{C} 2] 13 \%\end{array}$ \\
\hline & & 1220.9 & 1221.9 & 1129.7 & $\nu[\mathrm{C} 3-\mathrm{C} 4] 38 \%$ & 1172.7 & & 1192.3 & 1199.9 & 1139.3 & $\begin{array}{l}\delta[\mathrm{C} 3-\mathrm{C} 4-\mathrm{H}] 12 \% \\
\delta[\mathrm{C} 3-\mathrm{C} 6-\mathrm{H}] 12 \%\end{array}$ \\
\hline & & 1231.0 & 1237.5 & 1186.3 & $\nu[\mathrm{C} 1-\mathrm{C} 2] 12 \%$ & & $1203 \pm 15$ & 1213.5 & 1209.0 & 1224.8 & $\begin{array}{l}\nu[\mathrm{C} 2-\mathrm{C} 1] 29 \% \\
\nu[\mathrm{C} 2-\mathrm{C} 5] 29 \%\end{array}$ \\
\hline $\begin{array}{l}1200.7 \\
1224.8 \\
1234.4 \\
1274.0\end{array}$ & $1240 \pm 15$ & 1283.3 & 1286.8 & 1279.5 & $\begin{array}{l}\nu[\mathrm{C} 1-\mathrm{C} 2] 19 \% \\
\nu[\mathrm{C} 2-\mathrm{C} 5] 11 \%\end{array}$ & 1222.9 & & 1217.8 & 1224.7 & 1246.4 & $\begin{array}{c}\nu[\mathrm{C} 2-\mathrm{C} 3] 21 \% \\
\delta[\mathrm{H} 1-\mathrm{O}-\mathrm{C} 2] 19 \% \\
\delta[\mathrm{C} 2-\mathrm{C} 3-\mathrm{H}] 10 \%\end{array}$ \\
\hline 1306.8 & $1288 \pm 15$ & 1292.5 & 1332.6 & 1289.8 & $\begin{array}{l}\nu[\mathrm{C} 2-\mathrm{C} 5] 14 \% \\
\nu[\mathrm{C} 2-\mathrm{C} 6] 13 \% \\
\end{array}$ & 1312.6 & & 1333.4 & 1351.5 & 1286.3 & $\begin{array}{l}\nu[\mathrm{C} 3-\mathrm{C} 6] 10 \% \\
\nu[\mathrm{C} 3-\mathrm{C} 4] 10 \% \\
\end{array}$ \\
\hline \multirow[t]{2}{*}{1339.6} & $1340 \pm 15$ & 1354.0 & 1371.6 & 1294.7 & 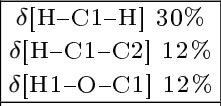 & 1318.3 & & 1349.0 & 1359.7 & 1322.7 & $\nu[\mathrm{O}-\mathrm{C} 2] 47 \%$ \\
\hline & & 1377.3 & 1384 & 1313.5 & $\nu[\mathrm{C} 2-\mathrm{C} 3] 22 \%$ & 1372.3 & & \begin{tabular}{|l|}
1382.0 \\
\end{tabular} & 1373.8 & 1344.7 & $\begin{array}{l}\delta[\mathrm{H}-\mathrm{C} 6-\mathrm{H}] 18 \% \\
\delta[\mathrm{H}-\mathrm{C} 4-\mathrm{H}] 18 \% \\
\delta[\mathrm{H}-\mathrm{C} 5-\mathrm{H}] 15 \% \\
\delta[\mathrm{H}-\mathrm{C} 1-\mathrm{H}] 14 \% \\
\end{array}$ \\
\hline 1363.7 & $1399 \pm 20$ & 1400.5 & 1399.3 & 1340.8 & $\begin{array}{c}\delta[\mathrm{H}-\mathrm{C} 1-\mathrm{H}] 25 \% \\
\delta[\mathrm{H} 1-\mathrm{O}-\mathrm{C} 1] 20 \% \\
\delta[\mathrm{H}-\mathrm{C} 3-\mathrm{H}] 18 \% \\
\nu[\mathrm{O}-\mathrm{C} 1] 11 \%\end{array}$ & 1384.9 & $1397 \pm 20$ & 1395.9 & 1399.9 & 1349.8 & $\begin{array}{l}\delta[\mathrm{H}-\mathrm{C} 4-\mathrm{H}] \\
\delta[\mathrm{H}-\mathrm{C} 6-\mathrm{H}] \\
\delta[\mathrm{H}-\mathrm{C} 1-\mathrm{H}] \\
12 \% \\
\delta[\mathrm{H}-\mathrm{C} 5-\mathrm{H}] \\
12 \%\end{array}$ \\
\hline 1380.0 & & 1411.7 & 1409.7 & \begin{tabular}{|l|}
1347.7 \\
\end{tabular} & $\begin{array}{c}\delta[\mathrm{H}-\mathrm{C} 3-\mathrm{H}] 20 \% \\
\delta[\mathrm{H} 1-\mathrm{O}-\mathrm{C} 1] \quad 16 \% \\
\end{array}$ & & & 1400.3 & 1401.3 & 1352.1 & $\begin{array}{l}\delta[\mathrm{H}-\mathrm{C} 5-\mathrm{H}] 31 \% \\
\delta[\mathrm{H}-\mathrm{C} 1-\mathrm{H}] 31 \%\end{array}$ \\
\hline \multirow[t]{5}{*}{1389.7} & & 1417.9 & 1416.3 & 1348.4 & $\begin{array}{l}\delta[\mathrm{H}-\mathrm{C} 5-\mathrm{H}] 51 \% \\
\delta[\mathrm{H}-\mathrm{C} 4-\mathrm{H}] \quad 17 \% \\
\end{array}$ & & & 1413.3 & 1414.9 & 1359.3 & $\begin{array}{l}\delta[\mathrm{H}-\mathrm{C} 5-\mathrm{H}] 32 \% \\
\delta[\mathrm{H}-\mathrm{C} 1-\mathrm{H}] 31 \%\end{array}$ \\
\hline & & 1456.1 & 1428.6 & 1352.2 & $\begin{array}{l}\delta[\mathrm{H}-\mathrm{C} 6-\mathrm{H}] 53 \% \\
\delta[\mathrm{H}-\mathrm{C} 5-\mathrm{H}] \quad 14 \% \\
\end{array}$ & & $1437 \pm 20$ & 1421.3 & 1424.9 & 1359.9 & $\begin{array}{l}\delta[\mathrm{H}-\mathrm{C} 6-\mathrm{H}] 42 \% \\
\delta[\mathrm{H}-\mathrm{C} 4-\mathrm{H}] 37 \% \\
\end{array}$ \\
\hline & & 1487.5 & 1488.9 & 1356.9 & $\begin{array}{l}\delta[\mathrm{H}-\mathrm{C} 6-\mathrm{H}] 52 \% \\
\delta[\mathrm{H}-\mathrm{C} 4-\mathrm{H}] 19 \%\end{array}$ & 1463.9 & $1454 \pm 20$ & 1481.5 & 1483.1 & 1361.6 & 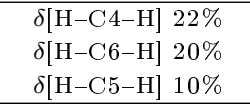 \\
\hline & & 1487.7 & 1489.8 & 1360.4 & $\begin{array}{l}\delta[\mathrm{H}-\mathrm{C} 6-\mathrm{H}] 27 \% \\
\delta[\mathrm{H}-\mathrm{C} 5-\mathrm{H}] 27 \% \\
\end{array}$ & & & 1483.6 & 1486.7 & 1365.4 & $\begin{array}{l}\delta[\mathrm{H}-\mathrm{C} 1-\mathrm{H}] 31 \% \\
\delta[\mathrm{H}-\mathrm{C} 5-\mathrm{H}] 28 \%\end{array}$ \\
\hline & & 1498.1 & 1494.3 & 1364.0 & $\begin{array}{l}\delta[\mathrm{H}-\mathrm{C} 4-\mathrm{H}] 61 \% \\
\delta[\mathrm{H}-\mathrm{C} 6-\mathrm{H}] 10 \%\end{array}$ & & & 1498.2 & 1494 & 1365.9 & $\begin{array}{l}\delta[\mathrm{H}-\mathrm{C} 4-\mathrm{H}] \\
\delta[\mathrm{H}-\mathrm{C} 6-\mathrm{H}] \\
\delta[\mathrm{H}-\mathrm{C} 5-\mathrm{H}] \\
11 \% \\
\end{array}$ \\
\hline \multirow[t]{2}{*}{1464.0} & $1461 \pm 20$ & 1504.1 & 1501.2 & 1369.5 & $\begin{array}{c}\nu[\mathrm{O}-\mathrm{C} 1] 19 \% \\
\delta[\mathrm{H} 1-\mathrm{O}-\mathrm{C} 1] 12 \% \\
\nu[\mathrm{C} 1-\mathrm{C} 2] 12 \%\end{array}$ & & & 1501.2 & 1499.7 & 1369.6 & $\begin{array}{l}\delta[\mathrm{H}-\mathrm{C} 6-\mathrm{H}] 12 \% \\
\delta[\mathrm{H}-\mathrm{C} 4-\mathrm{H}] 12 \%\end{array}$ \\
\hline & & 1511.9 & 1509.9 & 1369.7 & $\begin{array}{c}\delta[\mathrm{H}-\mathrm{C} 5-\mathrm{H}] 27 \% \\
\nu[\mathrm{C} 2-\mathrm{C} 5] 13 \%\end{array}$ & & & 1504.8 & 1509.5 & 1383.1 & $\begin{array}{l}\nu[\mathrm{C} 3-\mathrm{C} 6] 17 \% \\
\nu[\mathrm{C} 3-\mathrm{C} 4] 17 \% \\
\end{array}$ \\
\hline \multirow[t]{2}{*}{1475.5} & & 1512.8 & 1512.2 & 1380.4 & $\begin{array}{c}\nu[\mathrm{C} 2-\mathrm{C} 6] 28 \% \\
\delta[\mathrm{H}-\mathrm{C} 6-\mathrm{H}] 12 \% \\
\end{array}$ & & $1479 \pm 20$ & 1506.6 & 1513.4 & 1392.9 & $\begin{array}{c}\delta[\mathrm{H} 1-\mathrm{O}-\mathrm{C} 2] 40 \% \\
\nu[\mathrm{C} 2-\mathrm{C} 3] 18 \% \\
\end{array}$ \\
\hline & & 1520.2 & 1514.4 & 1391.1 & $\begin{array}{c}\nu[\mathrm{C} 3-\mathrm{C} 4] 20 \% \\
\delta[\mathrm{H}-\mathrm{C} 5-\mathrm{H}] 11 \% \\
\nu[\mathrm{C} 2-\mathrm{C} 5] 10 \%\end{array}$ & & & 1516.1 & 1515.6 & 1415.9 & 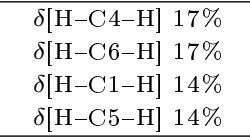 \\
\hline
\end{tabular}


TABLE II (cont.)

\begin{tabular}{|c|c|c|c|c|c|c|c|c|c|}
\hline & 1524.3 & 1523.1 & 1425.2 & $\begin{array}{c}\delta[\mathrm{H}-\mathrm{C} 5-\mathrm{H}] 21 \% \\
\delta[\mathrm{H}-\mathrm{C} 4-\mathrm{H}] 20 \% \\
\nu[\mathrm{C} 3-\mathrm{C} 4] 12 \% \\
\delta[\mathrm{C} 3-\mathrm{C} 4-\mathrm{H}] 11 \%\end{array}$ & & 1529.6 & 1522.2 & 1431.5 & $\begin{array}{ll}\delta[\mathrm{H}-\mathrm{C} 6-\mathrm{H}] & 10 \% \\
\delta[\mathrm{H}-\mathrm{C} 4-\mathrm{H}] & 10 \% \\
\delta[\mathrm{H}-\mathrm{C} 5-\mathrm{H}] & 10 \%\end{array}$ \\
\hline 2721.5 & 2959.2 & 2974.7 & 2828.4 & $\nu[\mathrm{C} 1-\mathrm{H}] 93 \%$ & $\begin{array}{l}2603.9 \\
2725.4\end{array}$ & 3004.1 & 3011.4 & 2764.9 & $\nu[\mathrm{C} 3-\mathrm{H}] 99 \%$ \\
\hline \multirow[t]{5}{*}{2873.7} & 2991.8 & 3008.3 & 2848.0 & $\nu[\mathrm{C} 3-\mathrm{H}] 99 \%$ & 2879.7 & 3019.2 & 3019.7 & 2941.5 & $\begin{array}{l}\nu[\mathrm{C} 6-\mathrm{H}] 27 \% \\
\nu[\mathrm{C} 4-\mathrm{H}] 26 \% \\
\nu[\mathrm{C} 5-\mathrm{H}] 15 \% \\
\nu[\mathrm{C} 1-\mathrm{H}] 15 \%\end{array}$ \\
\hline & 2998.8 & 3014.7 & 2914.2 & $\nu[\mathrm{C} 1-\mathrm{H}] 90 \%$ & 2941.4 & 3026.1 & 3025.8 & 2943.4 & $\begin{array}{l}\nu[\mathrm{C} 4-\mathrm{H}] 26 \% \\
\nu[\mathrm{C} 6-\mathrm{H}] 26 \% \\
\nu[\mathrm{C} 1-\mathrm{H}] 16 \% \\
\nu[\mathrm{C} 5-\mathrm{H}] 15 \%\end{array}$ \\
\hline & 3021.2 & 3020.8 & 2916.1 & $\nu[\mathrm{C} 3-\mathrm{H}] 93 \%$ & & 3032.3 & 3027 & 2954.4 & $\begin{array}{l}\nu[\mathrm{C} 5-\mathrm{H}] 26 \% \\
\nu[\mathrm{C} 1-\mathrm{H}] 25 \% \\
\nu[\mathrm{C} 4-\mathrm{H}] 14 \% \\
\nu[\mathrm{C} 6-\mathrm{H}] 14 \%\end{array}$ \\
\hline & 3026.6 & 3028.1 & 2936.1 & $\begin{array}{c}\nu[\mathrm{C} 5-\mathrm{H}] 43 \% \\
\nu[\mathrm{C} 4-\mathrm{H}] 39 \%\end{array}$ & & 3037.8 & 3032.2 & 2956.1 & $\begin{array}{l}\nu[\mathrm{C} 1-\mathrm{H}] 26 \% \\
\nu[\mathrm{C} 5-\mathrm{H}] 25 \% \\
\nu[\mathrm{C} 4-\mathrm{H}] 15 \% \\
\nu[\mathrm{C} 6-\mathrm{H}] 14 \%\end{array}$ \\
\hline & 3028.3 & 3058.0 & 2948.4 & $\begin{array}{l}\nu[\mathrm{C} 4-\mathrm{H}] 42 \% \\
\nu[\mathrm{C} 5-\mathrm{H}] 37 \%\end{array}$ & & 3073.9 & 3077.9 & 2977.6 & $\begin{array}{l}\nu[\mathrm{C} 6-\mathrm{H}] 54 \% \\
\nu[\mathrm{C} 4-\mathrm{H}] 44 \%\end{array}$ \\
\hline \multirow[t]{7}{*}{2964.1} & 3032.5 & 3065.2 & 2970.5 & $\nu[\mathrm{C} 6-\mathrm{H}] 93 \%$ & & 3082.6 & 3078.5 & 2978.6 & $\begin{array}{l}\nu[\mathrm{C} 4-\mathrm{H}] 54 \% \\
\nu[\mathrm{C} 6-\mathrm{H}] 45 \%\end{array}$ \\
\hline & 3083.8 & 3072.1 & 2973.2 & $\nu[\mathrm{C} 5-\mathrm{H}] 83 \%$ & & 3089.7 & 3085 & 2979.9 & $\begin{array}{l}\nu[\mathrm{C} 5-\mathrm{H}] 75 \% \\
\nu[\mathrm{C} 1-\mathrm{H}] 25 \% \\
\end{array}$ \\
\hline & 3085.2 & 3077.4 & 2975.3 & $\nu[\mathrm{C} 6-\mathrm{H}] 73 \%$ & & 3094.3 & 3088 & 2980.7 & $\begin{array}{l}\nu[\mathrm{C} 1-\mathrm{H}] 75 \% \\
\nu[\mathrm{C} 5-\mathrm{H}] 24 \%\end{array}$ \\
\hline & 3091.2 & 3084.5 & 2977.5 & $\nu[\mathrm{C} 4-\mathrm{H}] 92 \%$ & & 3106.2 & 3098.5 & 3050.8 & $\begin{array}{l}\nu[\mathrm{C} 6-\mathrm{H}] 52 \% \\
\nu[\mathrm{C} 4-\mathrm{H}] 33 \%\end{array}$ \\
\hline & 3098.1 & 3089 & 3045.5 & $\begin{array}{l}\nu[\mathrm{C} 5-\mathrm{H}] 82 \% \\
\nu[\mathrm{C} 4-\mathrm{H}] 17 \%\end{array}$ & & 3110.7 & 3108.6 & 3052.2 & $\begin{array}{l}\nu[\mathrm{C} 6-\mathrm{H}] 51 \% \\
\nu[\mathrm{C} 5-\mathrm{H}] 42 \%\end{array}$ \\
\hline & 3111.8 & 3095.7 & 3052.7 & $\nu[\mathrm{C} 4-\mathrm{H}] 97 \%$ & & 3122.3 & 3117.4 & 3053.2 & $\nu[\mathrm{C} 5-\mathrm{H}] 85 \%$ \\
\hline & 3115.4 & 3097.4 & 3057.6 & $\nu[\mathrm{C} 6-\mathrm{H}] 97 \%$ & & 3123.2 & 3124.3 & 3054.2 & $\nu[\mathrm{C} 6-\mathrm{H}] 81 \%$ \\
\hline 3351 & 3850.7 & 3839.0 & 3735.3 & $\nu[\mathrm{H} 1-\mathrm{O}] 100 \%$ & 3389.9 & \begin{tabular}{|l|}
3826.1 \\
\end{tabular} & 3821.9 & 3758.9 & $\nu[\mathrm{H} 1-\mathrm{O}] 100 \%$ \\
\hline
\end{tabular}

$\chi$ - torsion mode, $\delta$ - deformational mode, $\nu$ - stretching mode.

TABLE III

Geometrical parameters for $\mathrm{O}-\mathrm{H}$...O hydrogen bonds calculated for 2,2-dimethylbutan-1-ol and 2,3-dimethylbutan-2-ol in hydrogen bonded clusters.

\begin{tabular}{|c|c|c|c|c|c|c|c|c|}
\hline \multirow{3}{*}{ Bond } & \multicolumn{4}{|c|}{ 2,2-DM-1-B } & \multicolumn{4}{|c|}{ 2,3-DM-2-B } \\
\hline & Monomer & Dimer & Trimer & Tetramer & Monomer & Dimer & Trimer & Tetramer \\
\hline & \multicolumn{4}{|c|}{ length $[\AA]$} & \multicolumn{4}{|c|}{ length $[\AA]$} \\
\hline $\mathrm{O} 1-\mathrm{H} 1$ & 0.96071 & 0.96977 & 0.98232 & 0.98953 & 0.96246 & 0.97034 & 0.95952 & 0.96272 \\
\hline $\mathrm{O} 2-\mathrm{H} 2$ & & 0.96152 & 0.98501 & 0.99108 & & 0.96393 & 0.96014 & 0.96147 \\
\hline O3-H3 & & & 0.98474 & 0.99161 & & & 0.95268 & 0.96312 \\
\hline $\mathrm{O} 4-\mathrm{H} 4$ & & & & 0.99102 & & & & 0.96413 \\
\hline $\mathrm{O} 1-\mathrm{H} 4$ & & & & 1.74274 & & & & 1.81374 \\
\hline $\mathrm{O} 2-\mathrm{H} 1$ & & 1.88760 & 1.88567 & 1.73292 & & 1.91697 & 1.82820 & 1.82555 \\
\hline $\mathrm{O} 3-\mathrm{H} 2$ & & & 1.85040 & 1.73782 & & & 1.83308 & 1.81672 \\
\hline $\mathrm{O} 4-\mathrm{H} 3$ & & & & 1.71934 & & & & 1.83309 \\
\hline O1-H3 & & & 1.81293 & & & & & \\
\hline $\mathrm{O} 1 \ldots \mathrm{O} 2$ & & 2.85417 & 2.76442 & 2.69754 & & 2.88178 & 2.77027 & 2.75710 \\
\hline $\mathrm{O} 2 \ldots \mathrm{O} 3$ & & & 2.76350 & 2.71353 & & & 2.68224 & 2.67601 \\
\hline $\mathrm{O} 1 \ldots \mathrm{O} 3$ & & & 2.71873 & & & & & \\
\hline $\mathrm{O} 3 \ldots \mathrm{O} 4$ & & & & 2.68823 & & & & 2.76576 \\
\hline O4...O1 & & & & 2.71935 & & & & 2.66369 \\
\hline
\end{tabular}


For 2,3-DM-2-B the torsional out-of-plane $\chi[\mathrm{C}-\mathrm{C}]$ modes were predicted (in $\mathrm{cm}^{-1}$ ) in the range from 65.8 to $262.9 \mathrm{~cm}^{-1}$ by the DFT/B3LYP $/ 6-311 \mathrm{G}^{* *}$ method while from 102.3 to $273 \mathrm{~cm}^{-1}$ by the PM3 method. In the $G(\nu)$ spectra the band at $42.3,72.6,94.7,107.7$, and $123.4 \mathrm{~cm}^{-1}$ are coupled with the lattice branches, and the nice separated intramolecular modes are at 182.3, 205.2, $235.1,261.2$, and $297.9 \mathrm{~cm}^{-1}$. The last one was assigned as methyl's torsion.

Deformational in-plane modes of the $\delta\left[\mathrm{C}-\mathrm{C} 2-\mathrm{C}_{\mathrm{m}}\right]$ type $\left(\mathrm{C}_{\mathrm{m}}\right.$ is $\mathrm{C} 1, \mathrm{C} 4, \mathrm{C} 5$ or $\mathrm{C} 6$ of methyl, using carbon notation as in Fig. 1c,d) were predicted in the range from 299.2 to $579.9 \mathrm{~cm}^{-1}$ (from 273 to $579.9 \mathrm{~cm}^{-1}$ by the PM3) and were observed in the range from 340 to $642 \mathrm{~cm}^{-1}$ in the $G(\nu)$ spectra at $20 \mathrm{~K}$. The stretching modes of the $\nu\left[\mathrm{C} 2-\mathrm{C}_{\mathrm{m}}\right]$ type, predicted in the range between 704.2 and $855.9 \mathrm{~cm}^{-1}$ (789.3 and $928.4 \mathrm{~cm}^{-1}$ by the PM3) correspond to weak modes at 775 and $865.7 \mathrm{~cm}^{-1}$ in the neutron spectroscopy.

The calculations of vibrational spectra by DFT/ B3LYP /6-311G** (PM3) method give the position of deformational in-plane $\delta\left[\mathrm{C}-\mathrm{C}_{\mathrm{m}}-\mathrm{H}_{\mathrm{m}}\right]$ modes in the range from 917.9 to $975.2 \mathrm{~cm}^{-1}\left(933.7\right.$ to $\left.982.5 \mathrm{~cm}^{-1}\right)$. In $G_{\exp }(\nu)$ spectra they are at $927.6,958$, and $984 \mathrm{~cm}^{-1}$, while in IR at $911.4,945.1,963.4,989.5 \mathrm{~cm}^{-1}$, respectively.

The symmetric and asymmetric stretching $\nu\left[\mathrm{C}_{\mathrm{m}}-\mathrm{H}_{\mathrm{m}}\right]$ modes in methyl groups were identified by the DFT (PM3) method between 3019.2 and $3122.3 \mathrm{~cm}^{-1}(2941.5$ and $3053.2 \mathrm{~cm}^{-1}$ ) and in the MIR spectra the broad band is lying at 2603.3, 2725.4, 2879.7, and $2941.4 \mathrm{~cm}^{-1}$.

\subsection{Hydrogen bonds}

Table III collects the $\mathrm{O}-\mathrm{H}$ and $\mathrm{O}$...O distances, characteristic for HB, calculated in the molecular clusters [41] of linear or cyclic form. Hydrogen bridge bonding in clusters was predicted (estimated) by the optimisation of their structure by the DFT method as shorter ones and consequently HB interaction [27-32] is stronger for 2,2-DM-1-B than that for 2,3-DM-2-B. Moreover, with increasing number of molecules in the cluster the $\mathrm{O}-\mathrm{H}$. . O distance decreases similarly as the $\mathrm{O}-\mathrm{H}$ bond. The energy of a hydrogen bond is significantly lower than that of a covalent bond, but it is stronger than dipolar or the London dispersion force energies $(<10 \mathrm{~kJ} / \mathrm{mol})$. Schematic structures of different clusters calculated for 2,2-DM-1-B and 2,3-DM-2-B are presented in Fig. 4a-f. The intermolecular O...O distances are marked. The clusters of the lowest energy [41] are formed for certain conformations of molecules, i.e., for the 2,2-DM-1-B dimer and trimer are composed of the trans conformations, while the cyclic tetramer consists of three trans and one gauche conformers. For 2,3-DM-2-B molecules dimer is formed of gauche and trans conformations, while the trimer and tetramer are built of gauche conformations.

Hydrogen bond vibration modes for normal hydrogen bonds may be determined by analysing the following $\mathrm{O}-\mathrm{H}$... O frequencies: $\mathrm{O}-\mathrm{H}$ stretching in region from
1700 to $3700 \mathrm{~cm}^{-1}$, $\mathrm{HB}$ in plane bending in region between 1700 and $1900 \mathrm{~cm}^{-1}$, HB out-of-plane bending in range from 400 to $900 \mathrm{~cm}^{-1}$, HB stretching in region from 50 to $600 \mathrm{~cm}^{-1}$, HB bending below $50 \mathrm{~cm}^{-1}$ [27]. In order to discuss the properties of HB in both studied isomers, the calculations of vibrational spectra for isolated molecule, dimer, trimer and cyclic tetramer were performed. They were collected with the experimental ones (neutron $G(\nu)$ and infrared absorption spectra) in Figs. 5-8, respectively. With increasing size of cluster the calculated frequencies of normal modes are changing. The calculated spectra for tetramer are the closest to the experimental ones. The common, characteristic frequencies of normal modes for both experimental method, assigned as in-plane $\delta$ and out-of-plane $\gamma$ for $\mathrm{O}-\mathrm{H}$. . . O interactions in 2,2-DM-1-B and 2,3-DM-2-B were collected in Table IV.

\section{TABLE IV}

The frequency of $\mathrm{O}-\mathrm{H}$...O hydrogen bonds observed in 2,2-dimethylbutan-1-ol and 2,3-dimethylbutan-2-ol. Meaning of the symbols is the following: $\delta$ - in plane and $\gamma$-out of plane deformational vibrations.

\begin{tabular}{c|c|c|c|c}
\hline \hline & \multicolumn{2}{|c|}{2.2 -dimethylbutan-1-ol } & \multicolumn{2}{c}{ 2.3-dimethylbutan-2-ol } \\
\hline \hline vibration & $\gamma[\mathrm{O}-\mathrm{H} \ldots \mathrm{O}]$ & $\delta[\mathrm{O}-\mathrm{H} \ldots \mathrm{O}]$ & $\gamma[\mathrm{O}-\mathrm{H} \ldots \mathrm{O}]$ & $\delta[\mathrm{O}-\mathrm{H} \ldots \mathrm{O}]$ \\
\cline { 2 - 5 } & \multicolumn{4}{|c}{$\left[\mathrm{cm}^{-1}\right]$} \\
\hline dimer & $\gamma_{1}=252.3$ & $\delta_{1}=1189.7$ & $\gamma_{1}=257.4$ & $\delta_{1}=1158.7$ \\
& $\gamma_{2}=684.5$ & $\delta_{2}=1251.3$ & $\gamma_{2}=612.5$ & $\delta_{2}=1441.7$ \\
trimer & $\gamma_{1}=709.9$ & $\delta_{1}=1217.9$ & $\gamma_{1}=323.4$ & $\delta_{1}=1159.7$ \\
& $\gamma_{2}=739.0$ & $\delta_{2}=1293.4$ & $\gamma_{2}=678.1$ & $\delta_{2}=1406.2$ \\
& $\gamma_{3}=762.2$ & $\delta_{3}=1365.8$ & $\gamma_{3}=701.7$ & $\delta_{3}=1442.1$ \\
tetramer & $\gamma_{1}=793.5$ & $\delta_{1}=1228.7$ & $\gamma_{1}=696.8$ & $\delta_{1}=1233.4$ \\
& $\gamma_{2}=864.7$ & $\delta_{2}=1229.1$ & $\gamma_{2}=769.6$ & $\delta_{2}=1376.4$ \\
& $\gamma_{3}=868.4$ & $\delta_{3}=1416.4$ & $\gamma_{3}=793.2$ & $\delta_{3}=1421.3$ \\
& $\gamma_{4}=884.7$ & $\delta_{4}=1422.2$ & $\gamma_{4}=864.9$ & $\delta_{4}=1450.3$
\end{tabular}

For 2,2-DM-1B the position of the $\nu[\mathrm{OH}]$ stretching vibrations mode of hydroxyl group in IR absorption was obviously discussed, as it was very flexible for hydrogen bond interaction. In IR absorption spectra recorded at room temperature broad band at $3356 \mathrm{~cm}^{-1}$ in $2,2-$ -DM-1-B appears. The DFT calculation performed for tetramer predicted it, without scaling, subsequently at: $3279,3368,3380$, and $3425 \mathrm{~cm}^{-1}$ as given in Fig. 7 . The calculated O...O distances in tetramer (in $\AA$ ) are: $2.69754,2.71353,2.68823$, and 2.71935 for $2,2-\mathrm{DM}-1-\mathrm{B}$. The data confirm the correlation between the position of stretching $\mathrm{O}-\mathrm{H}$ modes and the $\mathrm{O}-\mathrm{H}$. . .O distance proposed by Novak [28], on the ground of complementary experimental studies of vibrational spectroscopy versus the structural data for the compounds with different forces of $\mathrm{HB}$

The in-plane bending $\delta[\mathrm{O}-\mathrm{H} \ldots \mathrm{O}]$ vibrations are predicted (in $\mathrm{cm}^{-1}$ ) at 1228.7, 1229.1, 1416.4, and 1422.2. They also appear in IR spectra at 1339.6 and $1363.7 \mathrm{~cm}^{-1}$. The out-of-plane bending $\gamma[\mathrm{O}-\mathrm{H} . . \mathrm{O}]$ vibrations are expected at $793.5,864.7,868.4$, and 884.7 in $\mathrm{cm}^{-1}$. They are visible in the room temperature of FIR spectra at 865.1 and $875.7 \mathrm{~cm}^{-1}$. Visualization of the results of calculation performed for cyclic tetramer shows 
characteristic stretching and bending HB modes in close neighbourhood to that predicted by PM3 method (i.e., 93.5, 187.3, and $285.4 \mathrm{~cm}^{-1}$ ).

The calculated frequencies of out-of-plane $\gamma[\mathrm{O}-\mathrm{H}$...O and in-plane $\delta[\mathrm{O}-\mathrm{H} \ldots \mathrm{O}]$ normal vibrations are shifted towards higher frequencies with increasing number of molecules in the clusters (the so-called blue-shift) [29, 3133 , while the stretching $\nu[\mathrm{O}-\mathrm{H}]$ are shifted towards lower frequencies with increasing size of cluster (the so-called red-shift) [29, 31, 32].

Far-infrared spectra of 2,2-DM-1-B measured during cooling and heating are shown in Figs. 9a and b, respectively. The frequencies of vibrational modes originating from the hydroxyl group are shifted together with temperature change, i.e., 96,212 , and $371 \mathrm{~cm}^{-1}$.

For 2,3-DM-2-B the stretching $\nu[\mathrm{OH}]$ are predicted, without scaling, for tetramer (in $\mathrm{cm}^{-1}$ ) at 3362,3380 , 3432, and 3489. The calculated O...O distances in tetramer (in $\AA$ ) are: 2.75710, 2.67601, 2.76576 and 2.66369 in 2,3-DM-2-B, respectively. In FIR absorption spectra in liquid phase recorded at $290 \mathrm{~K}$ broad band at $3392 \mathrm{~cm}^{-1}$ appears.

The calculated in-plane bendings $\delta[\mathrm{O}-\mathrm{H} \ldots \mathrm{O}]$ for tetramer were obtained at $1233.4,1376.4,1421.3$ and $1450.3 \mathrm{~cm}^{-1}$ (Fig. 6). The absorption bands are visible in IR spectra at $1479,1222.9$, and $1147.6 \mathrm{~cm}^{-1}$.

The out-of-plane $\gamma[\mathrm{O}-\mathrm{H} . . \mathrm{O}]$ modes are predicted at $696.8,769.6,793.2$, and $864.9 \mathrm{~cm}^{-1}$. However, the experimental IR spectra give it at $700.2 \mathrm{~cm}^{-1}$. The characteristic stretching and bending HB modes may be predicted close to that for 2,2-DM-1-B.

The HB is stronger for 2,2-DM-1-B than for 2,3-DM-2-B due to a more elongated shape of the molecules of 1-butanol. The presence of HB leads to changes in the frequencies of vibrations of the hydroxyl group for each type of cluster: frequencies of the out-of-plane $\gamma[\mathrm{C}-\mathrm{O}-\mathrm{H}]$ and the in-plane $\delta[\mathrm{C}-\mathrm{O}-\mathrm{H}]$ vibrations are higher of $100 \%$ and $30 \%$, respectively, while the frequency of $\nu[\mathrm{O}-\mathrm{H}]$ stretching vibration band is lower of about $10 \%$ for both compounds (see arrows in Figs. 5-8). Growth of a number of molecules in the cluster improves agreement of the calculated and experimental frequencies of vibrations as shown in Figs. 5-8.

\section{Conclusion}

The comparison of the $G_{\exp }(\nu)$ spectra for crystalline and glassy states of 2,2-DM-1-B (Fig. 3a) clearly showed smear-out of the Van Hove phonon singularities and excess peak in density of states (boson peak) below $50 \mathrm{~cm}^{-1}$ in glass in respect to the crystal. Intensive bands observed in the spectra of the density of states correspond to the libration of methyl groups of molecules.

Quantum chemistry modelling of the 2,2-DM-1-B and 2,3-DM-2-B molecules displays different rotational conformations. The value of calculated total formation energy for optimised structure by DFT method is nearly the same for both studied isomers.
The $G_{\text {cal }}(\nu)$ calculated in isolated molecule approximation are in quantitative agreement with experimental ones, but cannot explain details of the $G_{\exp }(\nu)$ at frequencies below $500 \mathrm{~cm}^{-1}$. The low frequency internal rotation of molecular subunits of both isomers around the C2-C3 bond of carbon atoms is mixed with the lattice modes below $100 \mathrm{~cm}^{-1}$. The DFT modelling of vibrational spectra of small linear and cyclic clusters allow us to assign the vibrational modes observed by IR and IINS spectroscopy more precisely. Calculated positions of the out-of plane torsion of methyl group for cyclic tetramer by the B3LYP method well correlated with the experiment $G_{\exp }(\nu)$ data. Moreover, the low frequency modes lying in region of the lattice branch were also predicted.

The optimisation of the structure of the cluster gives the information on the chain length and chain conformation. The calculated distance between oxygen atoms arranged in intermolecular interaction in analysed different type of clusters is close to typical length of hydrogen bridge bond. Consequently, the characteristic hydrogen bond vibration modes were determined. Chain length and chain conformation correlate with the energy flow out of the $\mathrm{O}-\mathrm{H}$ oscillators into the rest of the molecules or molecular clusters [37]. Our data confirm the correlation between the position of stretching $\mathrm{O}-\mathrm{H}$ modes (red-shift) and the $\mathrm{O}-\mathrm{H}$...O distance proposed by Novak. The next calculated HB mode, deformational in-plane and out-of-plane show blue shifting with increasing the cluster size. Moreover, their coupling with external vibrations $\sigma[\mathrm{O}-\mathrm{H} \ldots \mathrm{O}]$ or/and phonon, which stretch, compress and deform the hydrogen bonds may be explained.

The predicted frequencies of vibrations of hydrogen bond of tetramer clusters give good agreement of experimental (IINS, FIR and MIR) dynamic spectra. Coupling of methyl and molecular librations as well as the origin of the $\sigma, \gamma$ and $\delta$ deformations of hydrogen bonds were shown in crystalline phase of DMB.

\section{Acknowledgments}

The DFT calculations have been performed at the PCSC in Poznań. Financial support under a grant of Polish Plenipotentiary at JINR for the FNLP cooperation with the INP at Kraków and the UAM at Poznań is gratefully acknowledged by authors.

\section{References}

[1] W. Dannhauser, L.W. Bahe, R.Y. Lin, A.F. Flueckinger, J. Chem. Phys. 43, 257 (1965).

[2] R.K. Chan, G.P. Johari, Conf. Electr. Insul. Diel. Phenom., Ann. Report 43, 331 (1974).

[3] G.P. Johari, Ann. N.Y. Acad. Sci. 279, 117 (1976).

[4] A. Dworkin, Faraday Disscuss. Chem. Soc. 69-71, 288 (1980-1981).

[5] R. Edelmann, Ph.D. Thesis, Ruhr University, Bochum 1990.

[6] R. Edelmann, U. Bardelmeier, A. Würflinger, J. Chem. Soc. Faraday Trans. 87, 1149 (1991). 
[7] E. Juszyńska, M. Massalska-Arodź, P.M. Zieliński, J. Ściesiński, Phase Transit. 79, 899 (2006).

[8] E. Juszyńska, P.M. Zieliński, M. Massalska-Arodź, J. Krawczyk, J. Ściesiński, Solid state polymorphism and dynamics of 2,2-dimethyl-1-butanol as studied by adiabatic calorimetry and dielectric spectroscopy, to be published.

[9] M. Gałązka, E. Juszyńska, P.M. Zieliński, Physica B 406, 4342 (2011).

[10] E. Juszyńska, Ph.D. Thesis, Institute of Nuclear Physics PAN, accessible on: www.ifj.edu.pl/ $\mathrm{SD} /$ rozprawy_dr/rozpr_Juszynska.pdf?lang=pl (in Polish), Kraków 2008.

[11] E. Juszyńska, M. Massalska-Arodź, P.M. Zieliński, J. Krawczyk, "The solid state polymorphism and dynamics of 2,3-dimethylbutan-2-ol (2,3-DM-2-B)", to be published.

[12] H. Suga, J. Phys., Condens. Matter 15, 1 (2003).

[13] R.M. White, T.H. Geballe, Long Range Order in Solids, Academic Press, New York 1979.

[14] J. Timmermans, J. Phys. Chem. Solids 18, 1 (1961).

[15] M. Massalska-Arodź, T. Nakamoto, T. Wasiutyński, J. Mayer, J. Krawczyk, M. Sorai, J. Chem. Thermodyn. 36, 877 (2004)

[16] E. Juszyńska, M. Massalska-Arodź, J. Mayer, I. Natkaniec, J. Krawczyk, P. Tracz, Solid State Phenom. 112, 89 (2006).

[17] E. Juszyńska, M. Massalska-Arodź, I. Natkaniec, J. Mayer, J. Krawczyk, Physica B 403, 109 (2008).

[18] E. Juszyńska, K. Hołderna-Natkaniec, M. Massalska-Arodź, I. Natkaniec, E. Ściesińska, J. Ściesiński, Acta Phys. Pol. A 113, 1131 (2008).

[19] I. Natkaniec, S.I. Bragin, J. Brankowski, J. Mayer, in: Proc. ICANS XII Meeting, Abington, 1993, RAL Report 94-025, Vol. I, 1994, p. 89.

[20] V.Yu. Kazimirov, I. Natkaniec, Commun. JINR, P14-2003-48, Dubna 2003.

[21] E.L. Bokhenkov, I. Natkaniec, E.F. Sheka, Sov. Phys. JETP 43, 536 (1976).

[22] W.B. Nelligan, D.J. LePoire, T.O. Brun, R. Kleb, J. Chem. Phys. 87, 5 (1987).

[23] K. Holderna-Natkaniec, W. Kasperkowiak, I. Natkaniec, A. Szyczewski, Physica B 350, 443 (2004).

[24] J. Wuttke, J. Hermandez, G. Li, G. Coddens, H.Z. Cummins, F. Fujara, W. Petry, H. Sillescu, Phys. Rev. Lett. 72, 3052 (1994).

[25] N.V. Surovtsev, S.V. Adichtchev, S.V. Rossler, M.A. Ramos, J. Phys., Condens. Matter 28, 223 (2004).

[26] A.P. Sokolov, E. Rossler, A. Kisliuk, D. Quitmann, Phys. Rev. Lett. 71, 2062 (1993).
[27] G.A. Jeffrey, An Introduction to Hydrogen Bonding, Oxford Uniwersity Press, New York 1997.

[28] A. Novak, Large Molecules, Structure and Bonding, Vol. 18, Springer, Berlin 1974, p. 177.

[29] J. Joseph, E.D. Jemmis, J. Am. Chem. Soc. 129, 4620 (2007).

[30] E.S. Kryachko, in: Hydrogen Bonding - New Insights, Ed. S.J. Grabowski, Springer, Dordrecht, The Netherlands 2006, Ch. 8.

[31] S. Scheiner, Hydrogen Bonding, Oxford University Press, New York 1997.

[32] G.R. Desiraju, T. Steiner, The Weak Hydrogen Bond, Oxford University Press, Oxford 1999.

[33] J.J.P. Stewart, J. Mol. Mod. 10, 155 (2004).

[34] P. Hohenberg, W. Kohn, Phys. Rev. B 136, 864 (1964).

[35] M.J. Frisch, G.W. Trucks, H.B. Schlegel, G.E. Scuseria, M.A. Robb, J.R. Cheeseman, J.A. Montgomery, Jr., T. Vreven, K.N. Kudin, J.C. Burant, J.M. Millam, S.S. Iyengar, J. Tomasi, V. Barone, B. Mennucci, M. Cossi, G. Scalmani, N. Rega, G.A. Petersson, H. Nakatsuji, M. Hada, M. Ehara, K. Toyota, R. Fukuda, J. Hasegawa, M. Ishida, T. Nakajima, Y. Honda, O. Kitao, H. Nakai, M. Klene, X. Li, J.E. Knox, H.P. Hratchian, J.B. Cross, V. Bakken, C. Adamo, J. Jaramillo, R. Gomperts, R.E. Stratmann, O. Yazyev, A.J. Austin, R. Cammi, C. Pomelli, J.W. Ochterski, P.Y. Ayala, K. Morokuma, G.A. Voth, P. Salvador, J.J. Dannenberg, V.G. Zakrzewski, S. Dapprich, A.D. Daniels, M.C. Strain, O. Farkas, D.K. Malick, A.D. Rabuck, K. Raghavachari, J.B. Foresman, J.V. Ortiz, Q. Cui, A.G. Baboul, S. Clifford, J. Cioslowski, B.B. Stefanov, G. Liu, A. Liashenko, P. Piskorz, I. Komaromi, R.L. Martin, D.J. Fox, T. Keith, M.A. Al-Laham, C.Y. Peng, A. Nanayakkara, M. Challacombe, P.M.W. Gill, B. Johnson, W. Chen, M.W. Wong, C. Gonzalez, J.A. Pople, GAUSSIAN 03, Revision D.01, Gaussian, Inc., Wallingford CT 2004.

[36] W.J. Hehre, L. Radom, P. v. R. Schleyer, J.A. Pople, Ab Initio Molecular Orbital Theory, Wiley, New York 1986.

[37] A.D. Becke, Phys. Rev. B 38, 3098 (1988).

[38] C. Lee, W. Yang, R.G. Parr, Phys. Rev. B 37, 785 (1988).

[39] R.G. Parr, W. Yang, Density Functional Theory of Atoms and Molecules, Oxford University Press, New York 1989.

[40] J. Tomkinson, A.J.J. Ramirez-Cuesta, S.F. Parker, $\alpha$-CLIMAX, ISIS Facility RAL CLRC Chilton.

[41] Y. Yamada, Y. Katsumoto, T. Ebata, Phys. Chem. Chem. Phys. 10, 1170 (2007). 